\title{
توظيف تكنولوجيا الوسائط المتعددة في تعليم اللغة العربية عن بعد
}

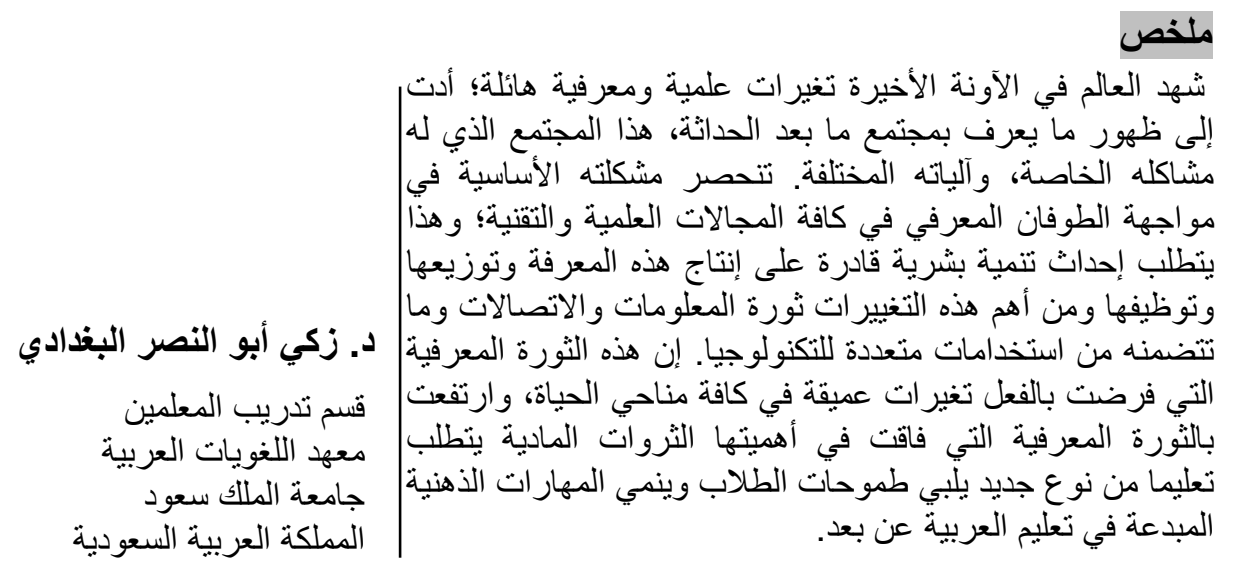

\section{Abstract}

* The world has recently witnessed tremendous scientific changes that lead to the emergence of a post-modernism community with specific problems and various mechanisms. Its major challenge is the flood of knowledge in scientific and technical domains which require the development of qualified human resources in order to create, manage, and use that knowledge. This revolutionary development appears in the field of information and communication technology and its multiple uses which have a deep impact on all aspects of life. The importance of this knowledge development becomes more significant than material resources as it requires efficient education that satisfies the students' ambitions and improves their cognitive and creative abilities in distance teaching of Arabic. 
أحدثت الوسائط المتعددة تغبيرا كبيرا في عمليات التدريس لما لها من مميزات،

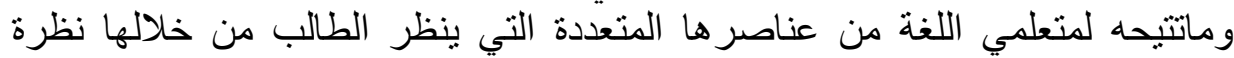

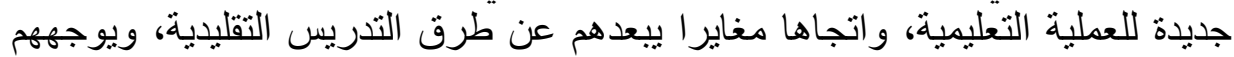

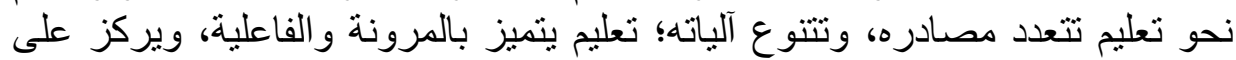

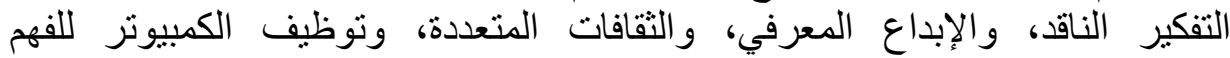

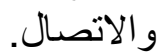

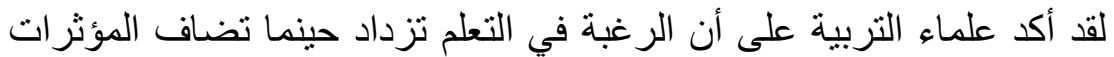

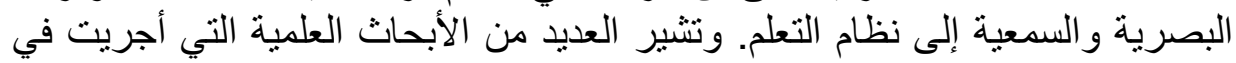

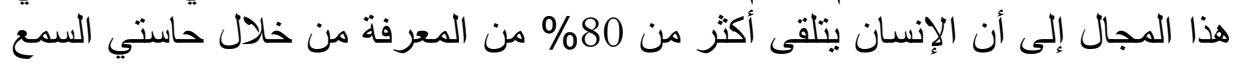
والبصر ونحو 13:20\% من خلال حاسة السمع،ويلي ذلك الحواس الأخرى التي من التئ تتراوح بين 1: 5 \% و هي حواس اللمس والتذوق و الثم. فما أحوجنا إلى توظيف هذه

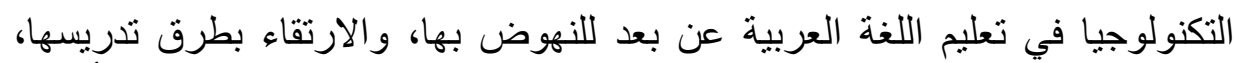

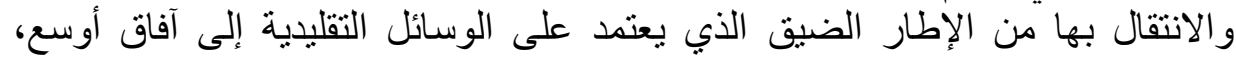

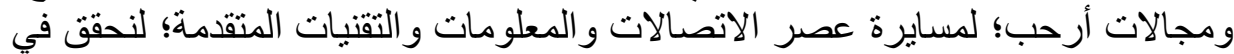

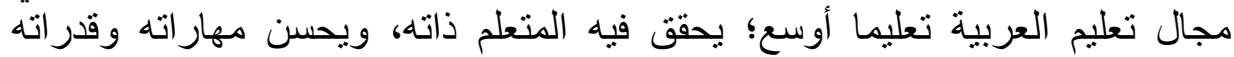

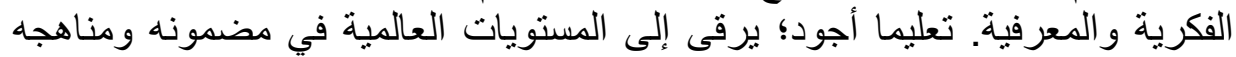

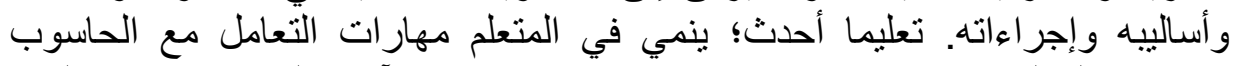

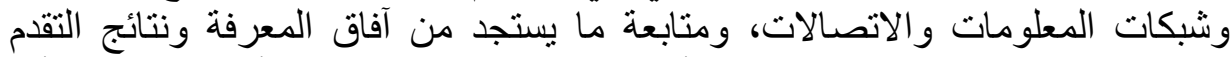

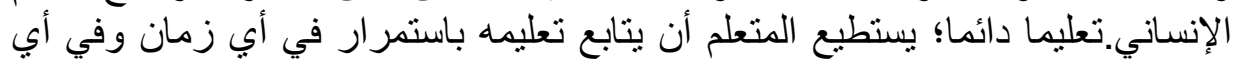

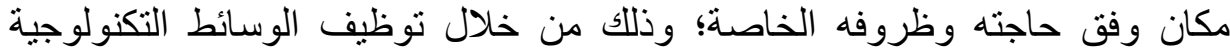

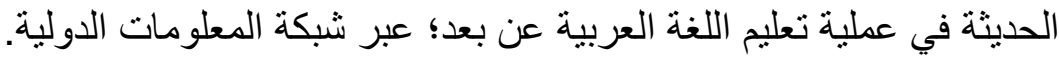

البحث يتناول عدة محاور وهي: تحديد مفهوم تكنولوجيا الوسائط المتعددة-

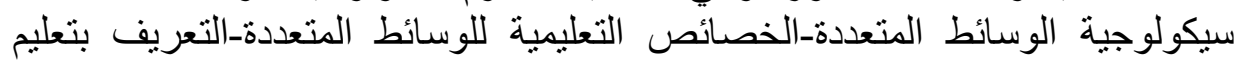

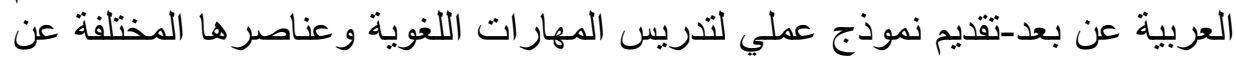

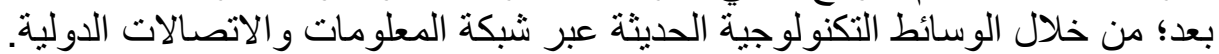

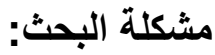

تكمن مشكلة البحث في ضرورة الاستفادة من المستحدثات التكنولوجية ووسائطها

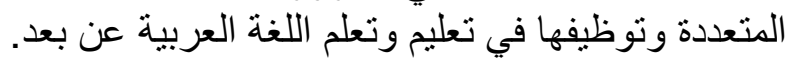

أسئلة البحث

يجيب البحث عن التساؤلات التالية:

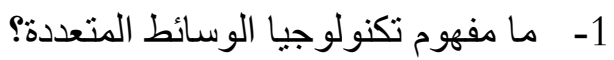


2- - ما سيكولوجية الوسائط المتعددة؟

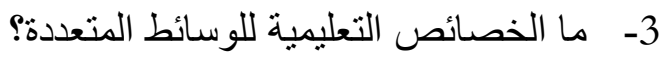

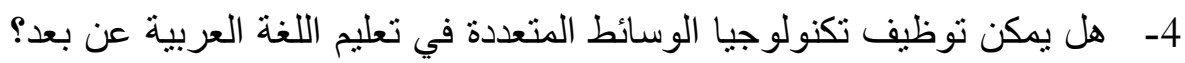

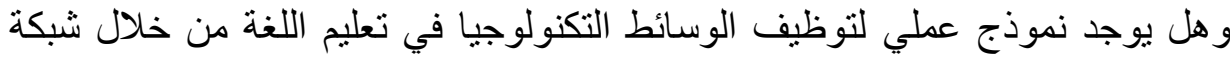
الإنترنت؟

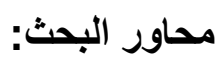

- - مفهوم تكنولوجيا الوسائط المتعددة. - - - - ميكولوجية الوسائط المتعددة.

-

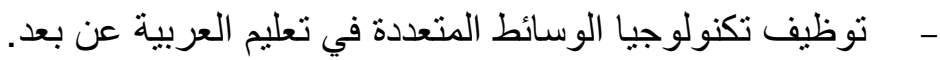

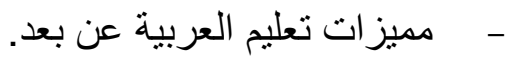

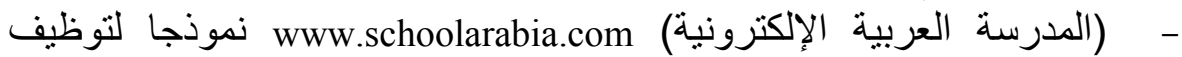
الوسائط المتعددة التفاعلية في تعليم العربية عن بعدة الإنية

$$
\text { أدوات البحث }
$$

اعتمد الباحث على المراجع العربية والأجنبية التي تناولت تكنولوجيا الوسائط

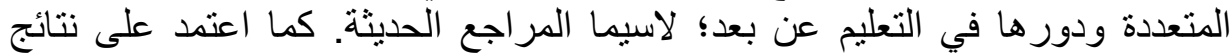

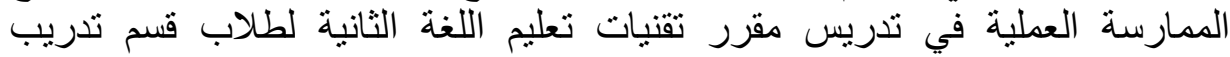

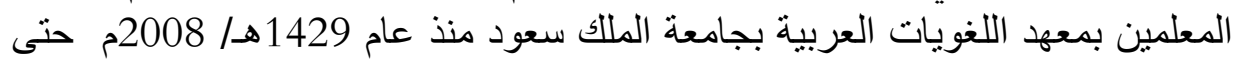

$$
\text { الوقت الر اهن }
$$

\section{الدراسات السابقة}

دراسة خالد محمد فرجون "الوسائط المتعددة بين التنظير و التطبيق،2004" والذي أثنار فيها إلى ضرورة استخلاص بعض الأسس النفسية والفنية عند تصميم وإنتاج

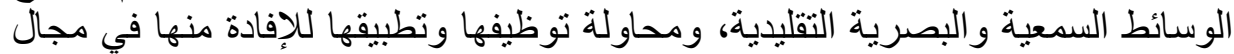

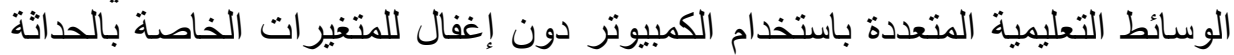

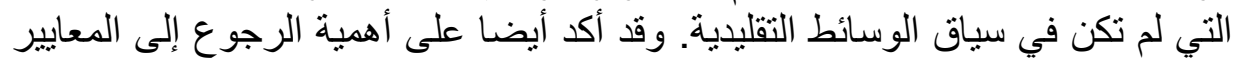

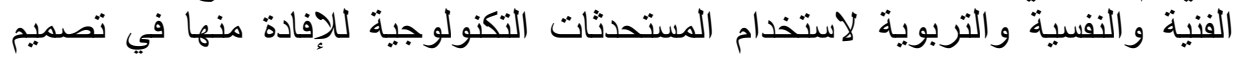
البرامج التعليمية حتى تتحقق معايير الجودة التعليمية الثناملة.

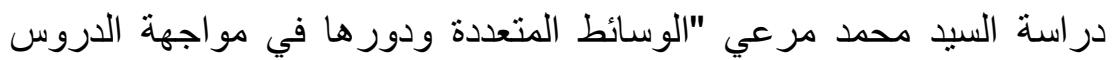
الخصوصية، 2009" والتي أكد فيها على أن استخدام جهاز الحاسب الطي الآلي -عموماـ

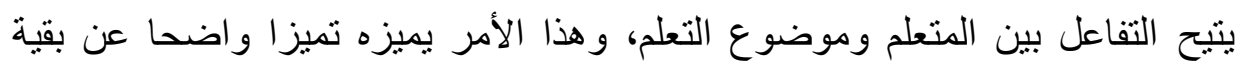


الأدوات التعليمية التي ظهرت قبله. كما أن الحاسب الآلي أدةتكنولوجية حديثة دخلت

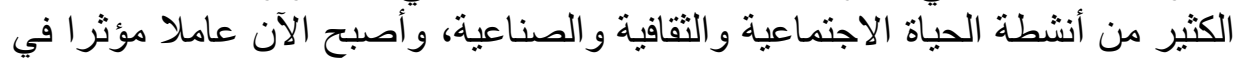

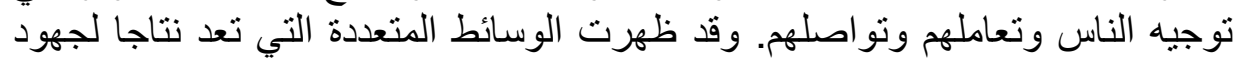

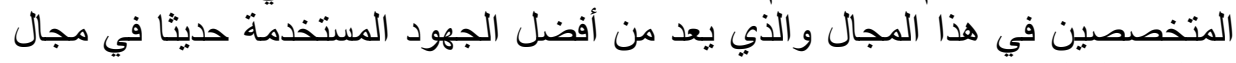

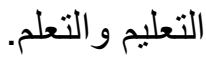

أكد الباحث أيضا في در استه السابقة على أهمية الاستفادة من عروض الوسائط

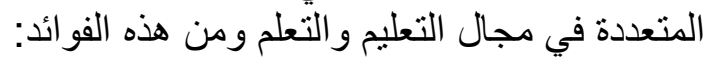
1- تدريس المفاهيم، والمبادئ، والحقائق المجردة هذون التي تحتاج إلى جهد كبير من الطلاب لفهمها و اكتسابها. 2- إتاحة الفرصة لكل طالب أن يتعلم بطريقة فردية، تعتمد على الخطو الذاتي له، و إتاحة الفرصة ليتعلم حسب الوقت المطلوب لتعلمه شخصيا. 3- مر اعاة الفروق الفردية بين الطلاب.

4- مساعدة المتعلمين على الابتكار والاكتشاف من خلال عروض لين الواقع 5- تقديم التغذية الر اجعة الفورية للطلاب.

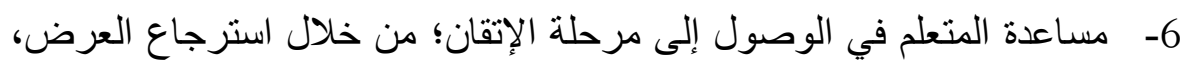
و الرجوع إلى النقاط الصعبة لدر استها. 7- إكساب الطلاب المهارات العقلية الر اقية؛مثل التفكير الإبداعي، وطرق حل المشكلات.

8- مساعدة الطلاب على تخيل للأشياء في بيئتها الحقيقية وتصور ها تصور ا يثبه

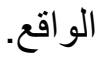

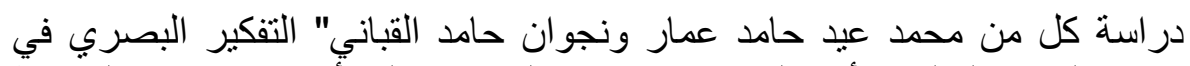

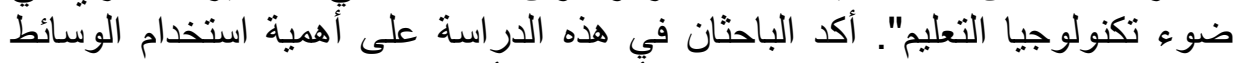

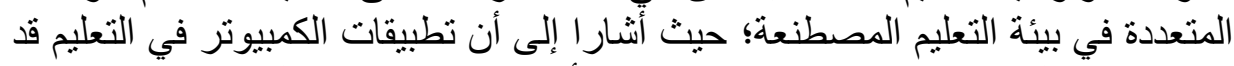

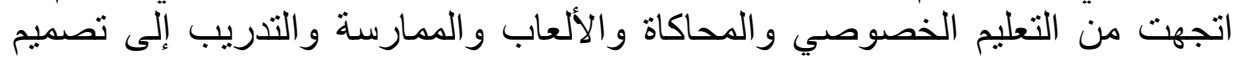

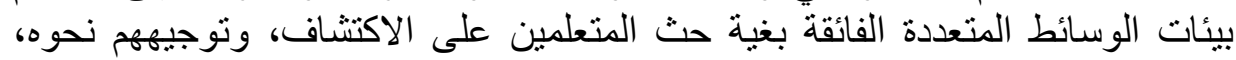

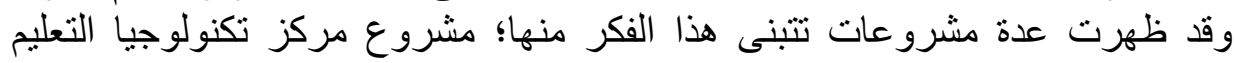

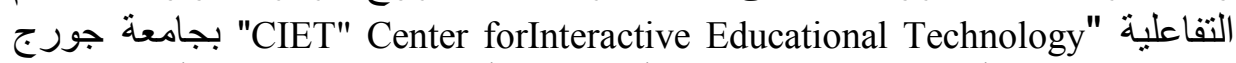
ماسون والذي بدأ عام 1990 كمرحلة أولية، إلا أن البداية الحقيقية بدأت من عام المعاج

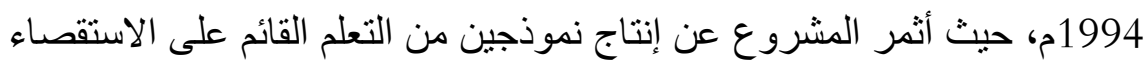




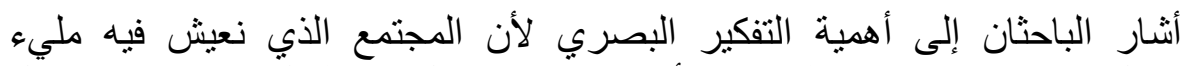

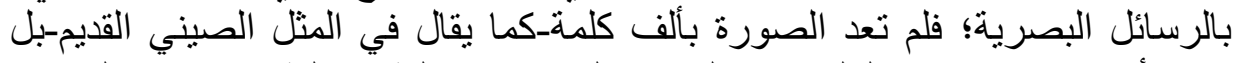
ربما أصبحت بملايين الكلمات؛ فالتفكير البصري عملية داخلية، تتضمن التهات التصور

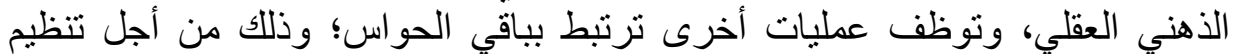

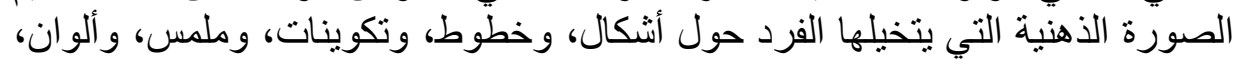
و غير ها من عناصر اللغة البصرية داخل المخ البشري.

\section{المبحث الأول: مفهوم تكنولوجيا الوسائط المتعددة}

تمهيد:

مما لا شك فيه أن للتكنولوجيا تأثثرا كبيرا في جميع المجالات وامتد هذا التأثير

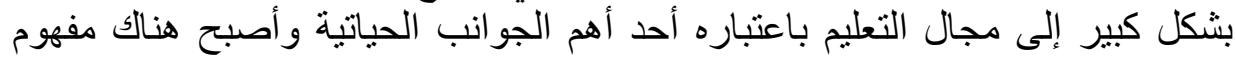

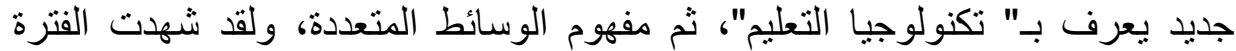

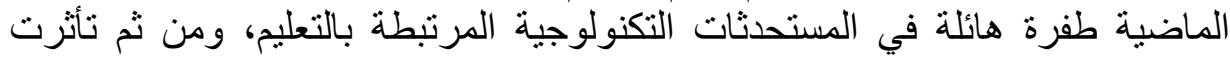

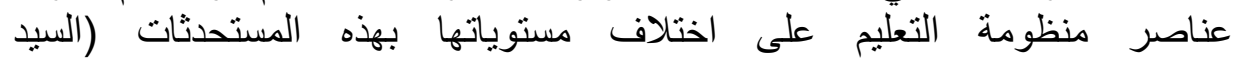

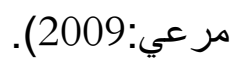

لقد تغير دور المعلم بصورة واضحة، و أصبحت كلمة (معلم/مدرس) غير مناسبة

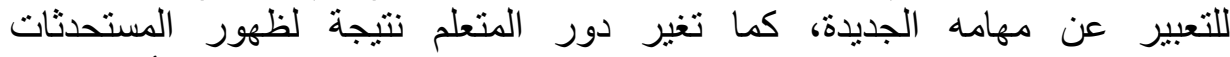

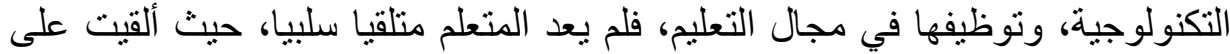

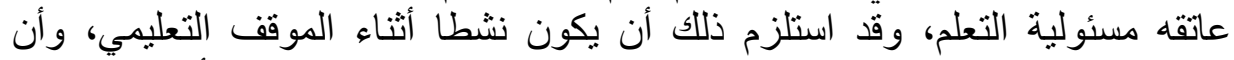

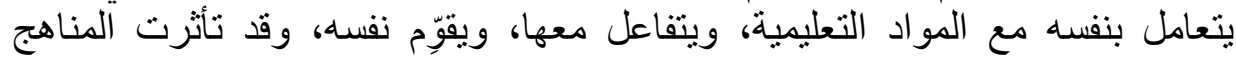

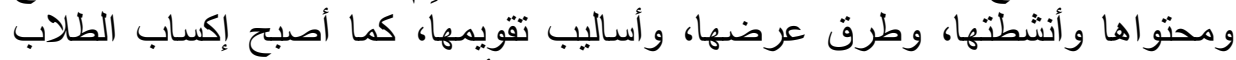

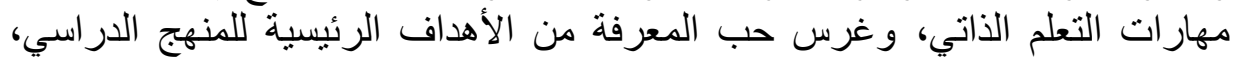

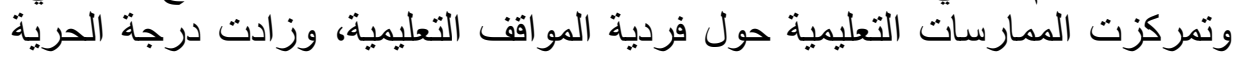

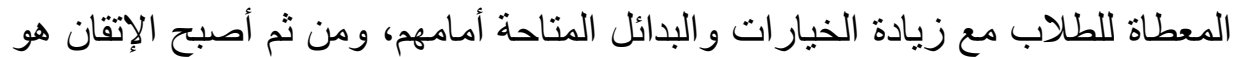

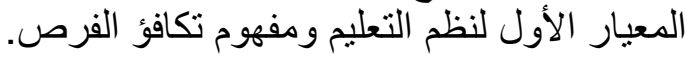

يؤكد العديد من الباحثين على أن هناك أسبابا عديدة عجلت بظهور المستحدثات

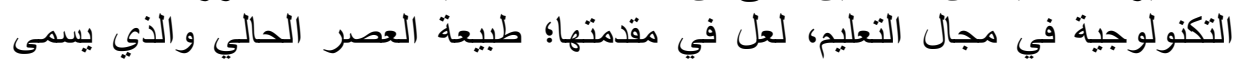

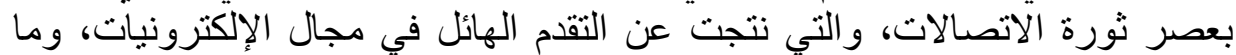

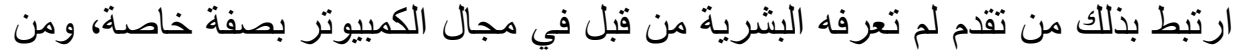

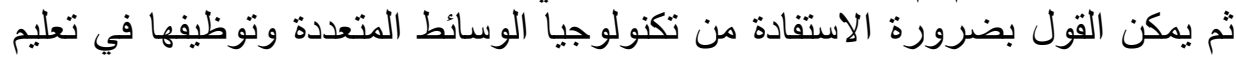

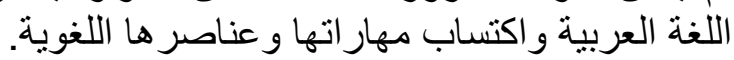
تعددت التعريفات والآراء حول مفهوم الوسائط المتعددة على النحو التالي: 
في اللغة نجد أن كلمة"Multi-Media" نتكون من مقطعين "Multi" ونعائة وتعنى متعدد وكلمة "Media"وتعني وسائط أو وسائل ومعناها؛ استخدام جملة من وسائل الاتصال

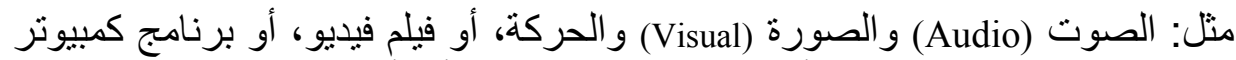

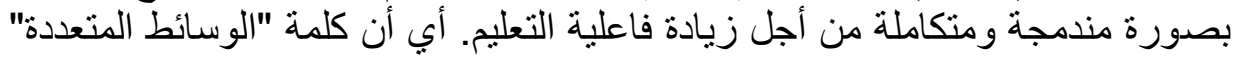

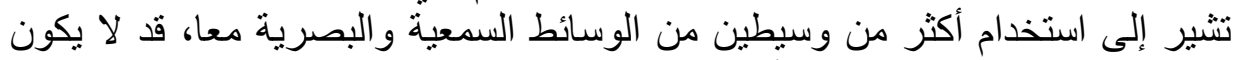

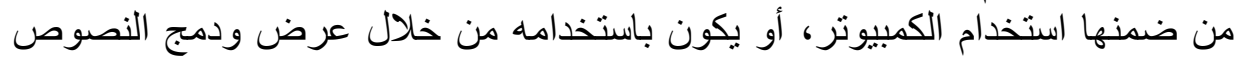

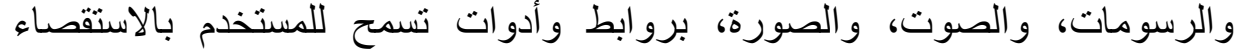

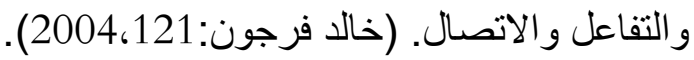

يشير على عبد المنعم إلى أنه يمكن النظر إلى الوسائط المتعددة على أنها أدوات

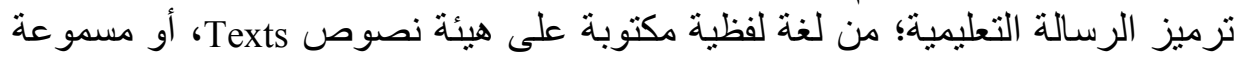

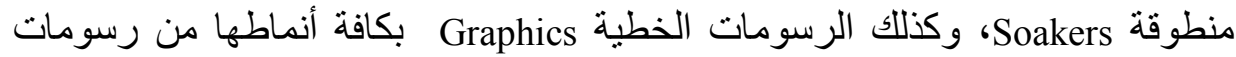

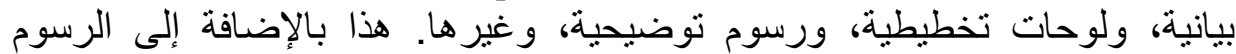

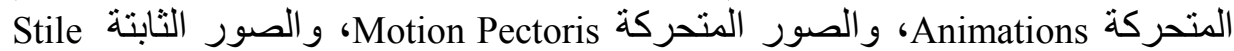
Pectoris

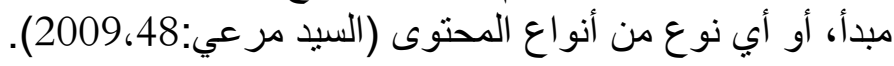

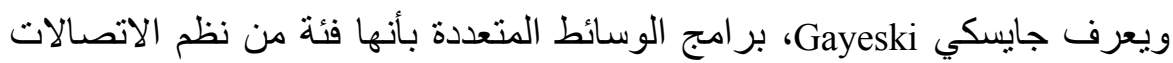

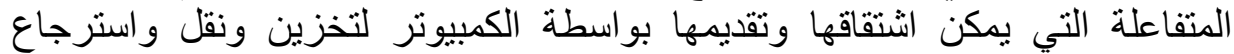

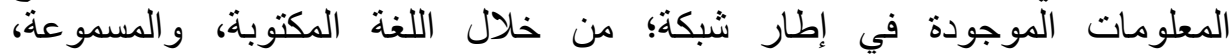

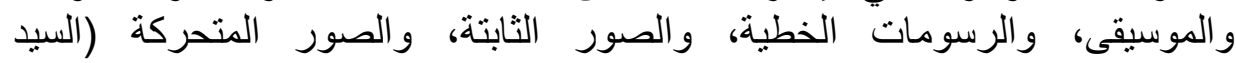
مر عي:2009).

يحدد(علي زين الدين:1996،68). مفهوم الوسائط المتعددة بقوله: طائفة من

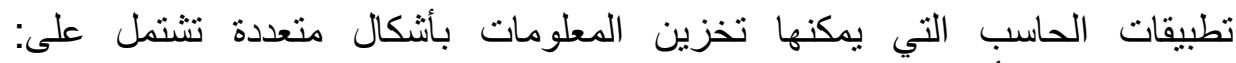

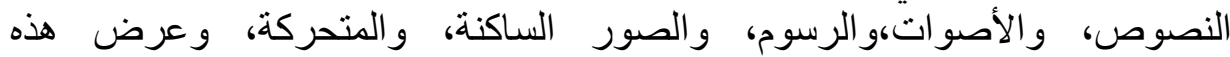
المعلومات بطريقة تفاعلية وفقا لمسار ات يتحكم فيها المستخدم.

يذكر حسين حسن موسى نقلا عن "أريك هولسينجر" تعريفه للوسائط المتعددة

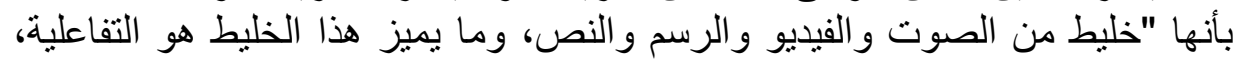

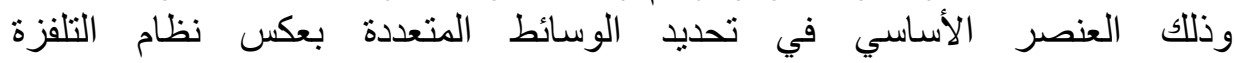

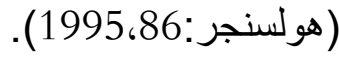

إن الوسائط المتعددة تمثل مزيجا من النصوص المكتوبة، والرسومات الخطية،

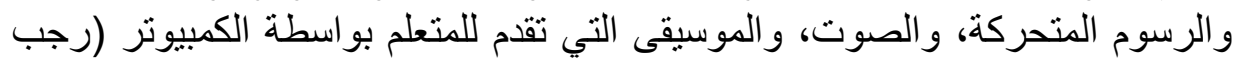
المبهي:5، (1997-12) - (12). 


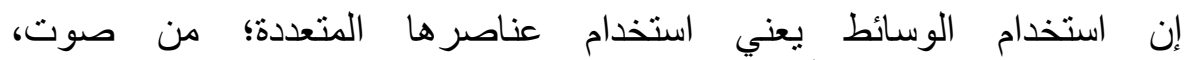

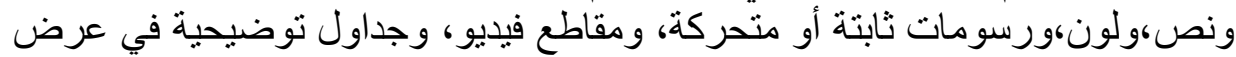

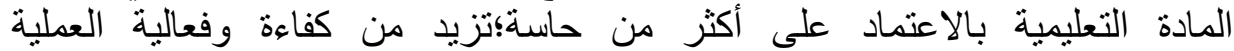

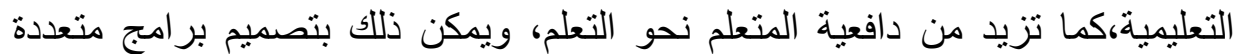

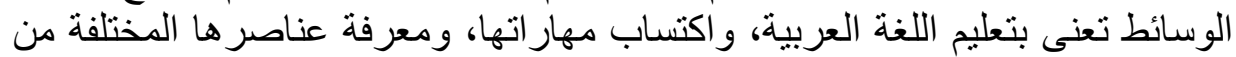
خلال التكامل بين النص والصنائ الصوت والصورة لتصبة واكبح العملية التعليمية عملية متكاملة

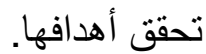

يرى الباحث أن الوسائط المتعددة منظومة تعليمية، تتكون من مجموعة من المواد المواد

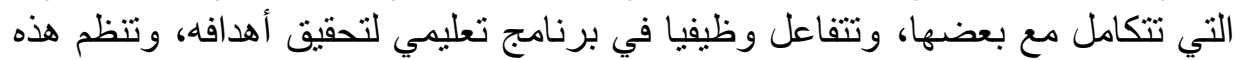

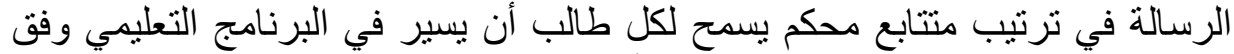

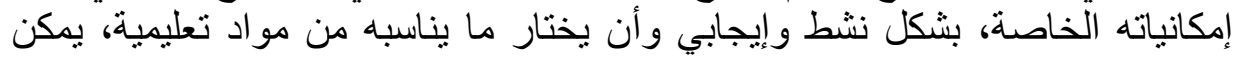

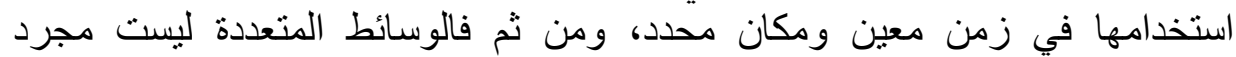

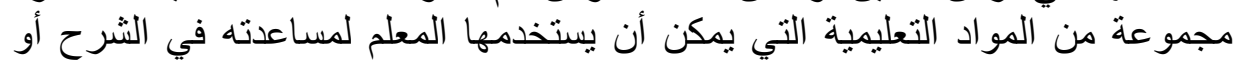

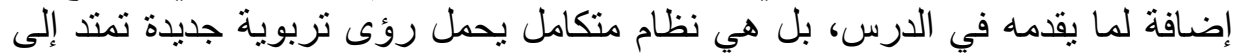

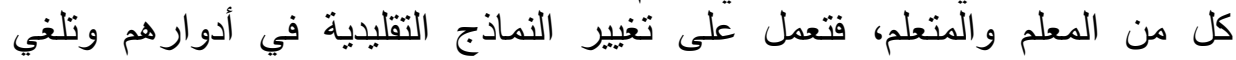

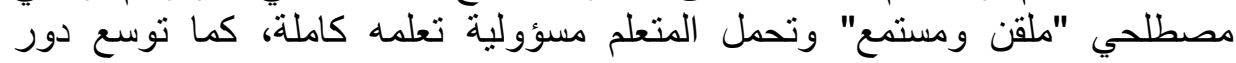

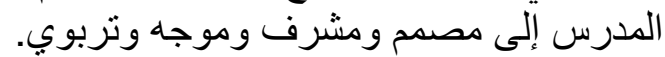

لقد تناول بعض الباحثين الوسائط المتعددة على أنها وسائط تقع تحت مظتلة

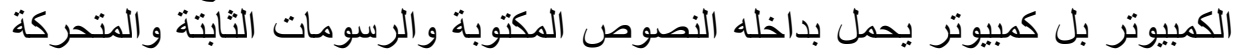

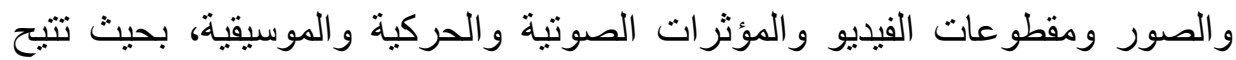

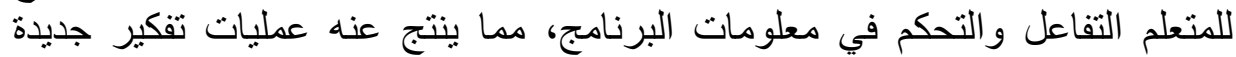

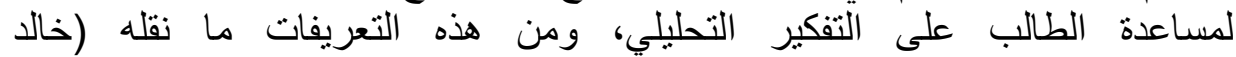
خرجون:123،2004) عن "ديرليوكينامان" بأنها تكوين بنائي رقمي يتكون من النص

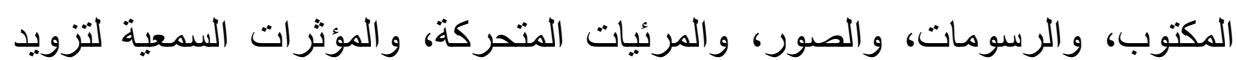

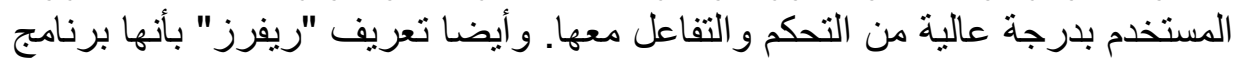

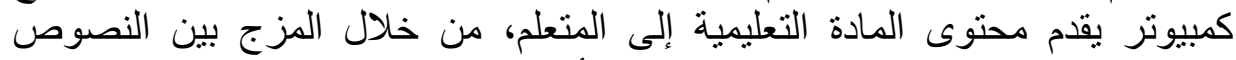

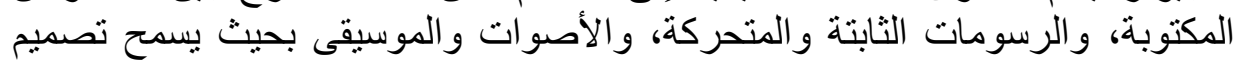

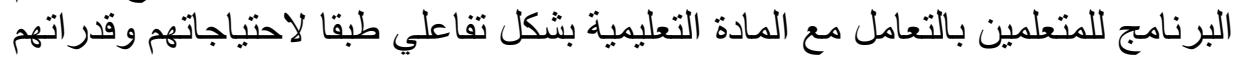
وخطو هم الذاتي.

في مجال التعليم يحمل مصطلح Multimedia System صفة توجيه و إدارة

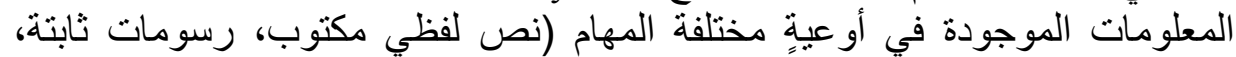

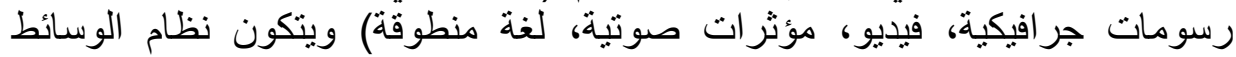

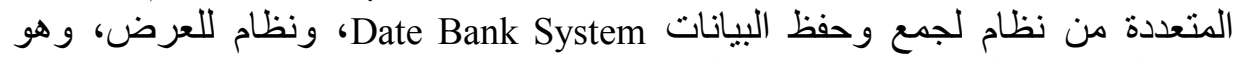
المسئول عن عمل تزامن بين الوسائل المختلفة المشتركة في حزمة الوسائط المتعددة، 
إضافة إلى الأجهزة المطلوبة التي تساعد في عمل البيانات و المساعدة في الحصول على أفضل النتائج عند دمج الوسائط معا.

\section{المبحث الثاني: سيكولوجية الوسائط المتعددة:}

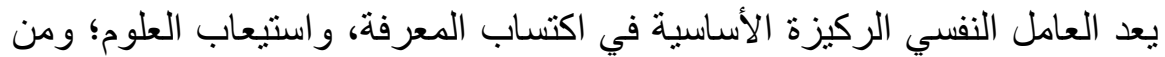

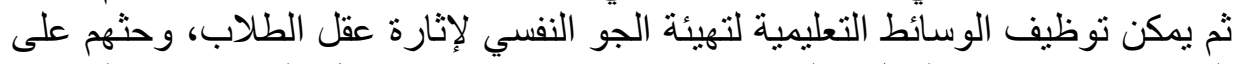

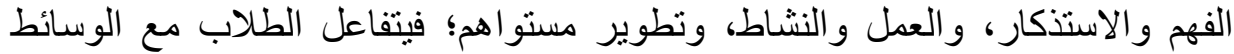

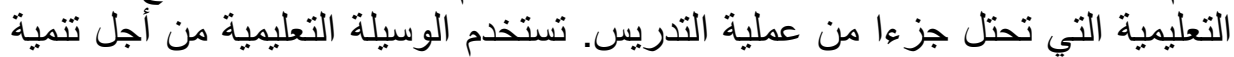

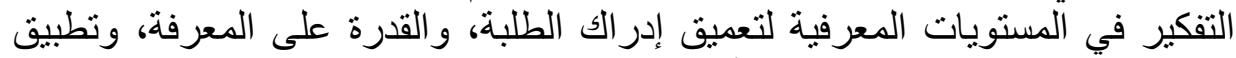

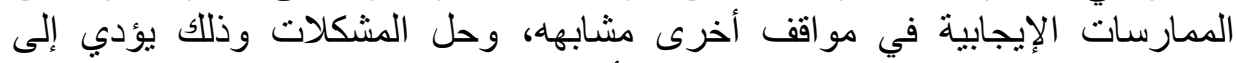
صناعة متعلم يتميز بالمهارة والإتقان لأن التان عملية التحفيز مرتبطة بدرجة كبيرة بالاتجاهات نحو التعلم و التفكير.

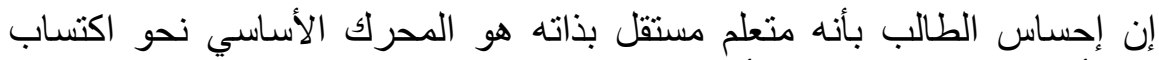

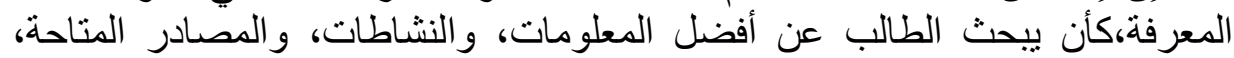

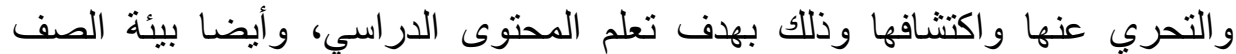

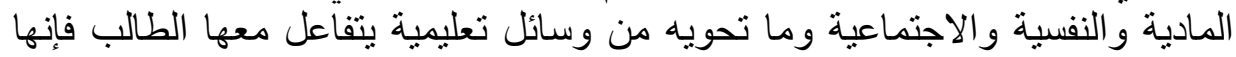

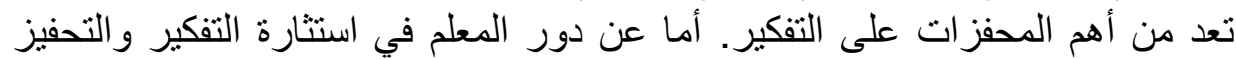

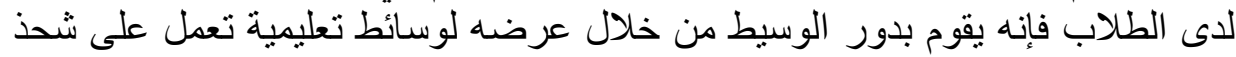

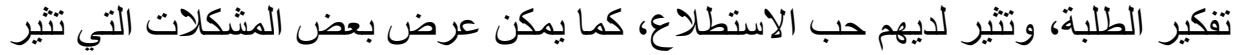

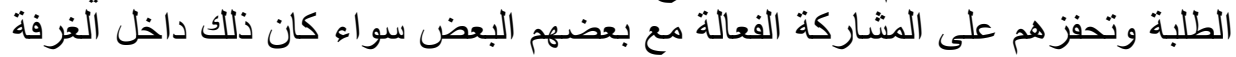

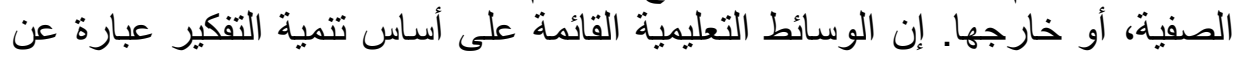

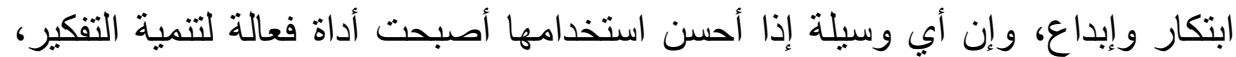
وتتويق الطلبة، و إثارة دافعيتهم للمادة التعليمية.

\section{الإدرالك الحسي للوسائط المتعددة:}

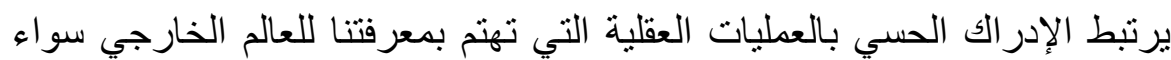

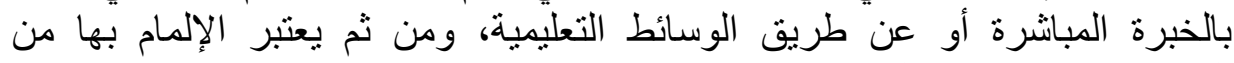

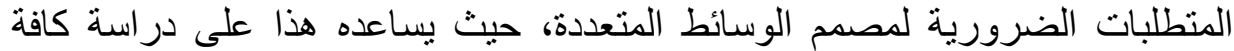

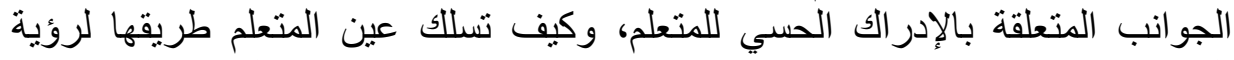

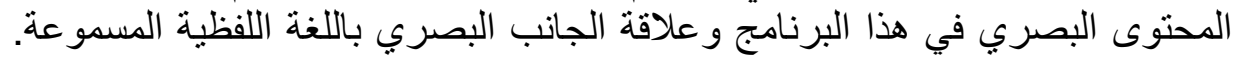

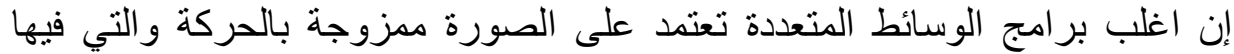

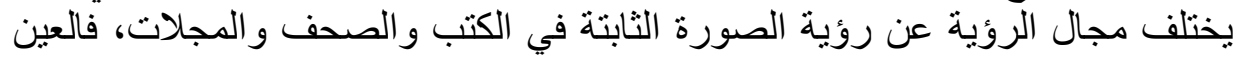

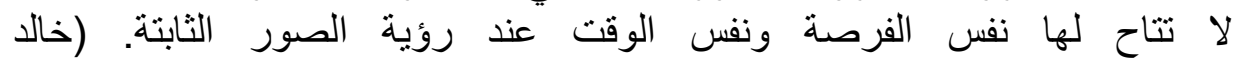
فرجون:19،2004)

المبحث الثالث: الخصائص التعليمية للوسائط المتعددة 
تمتاز الوسائط المتعددة بمجمو عة من الخصائص أهمها:

(Rohwedder \& Andy,2003) زيتون:133،134-2002)،(منال مبارز وسامح إسماعيل:16،2016-2010-39)؛(هشام العشري:93، (111-2011). 1 - 1 - التكامل: Integration:

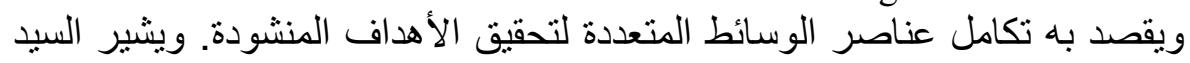

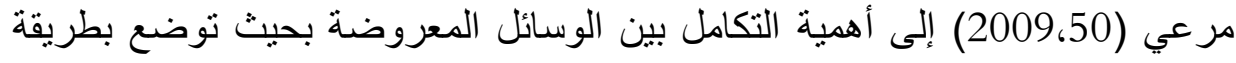

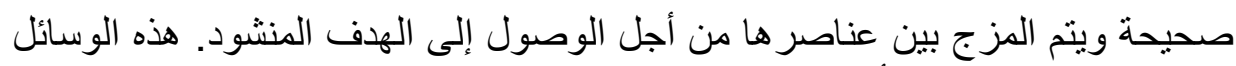

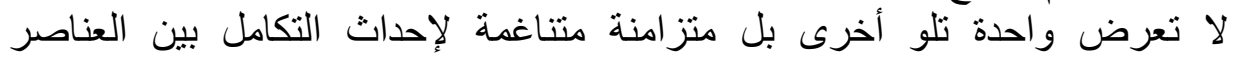
المعروضة.

2- التز امن Synchronization

التزامن يعني التوافق بين الأحداث المختلفة على الثاشتة الواحدة التي يتم عرضها،

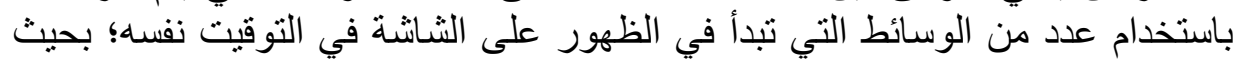

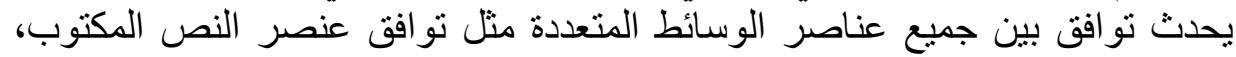

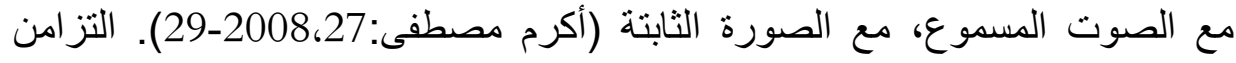

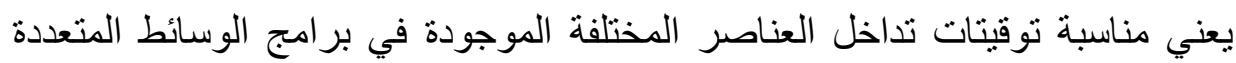

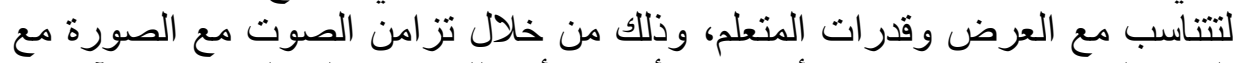

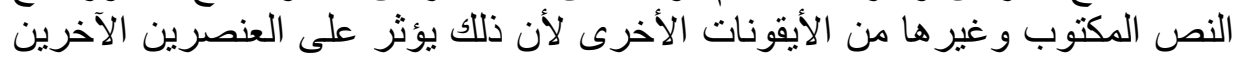

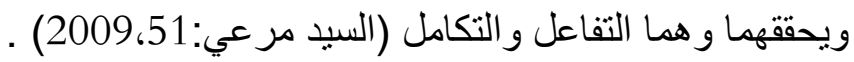

3- التفاعلية: Interactivity

تثير التفاعلية إلى عملية الفعل ورد الفعل من قبل المتعلم في التعامل مع برامج التعانج الكمبيوتر متعددة الوسائل. يوضح (Randall.2003) أن الوسائط المتعددة التفاعلية فئلية

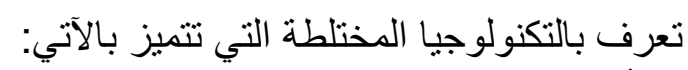

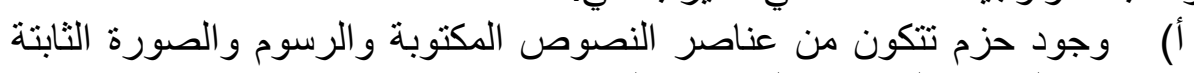

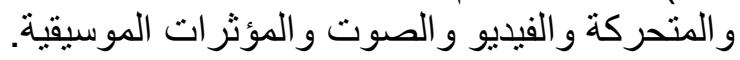
ب) تتكامل العناصر السابقة وتترابط فيما بينها بطريقة تسمح للعنية. للمستخدم من الاستعر اض والإبحار عبر تللك العناصر . 
وتلخص (زينب أمين:200،2000) مكونات الوسائط المتعددة التفاعلية في الثكل

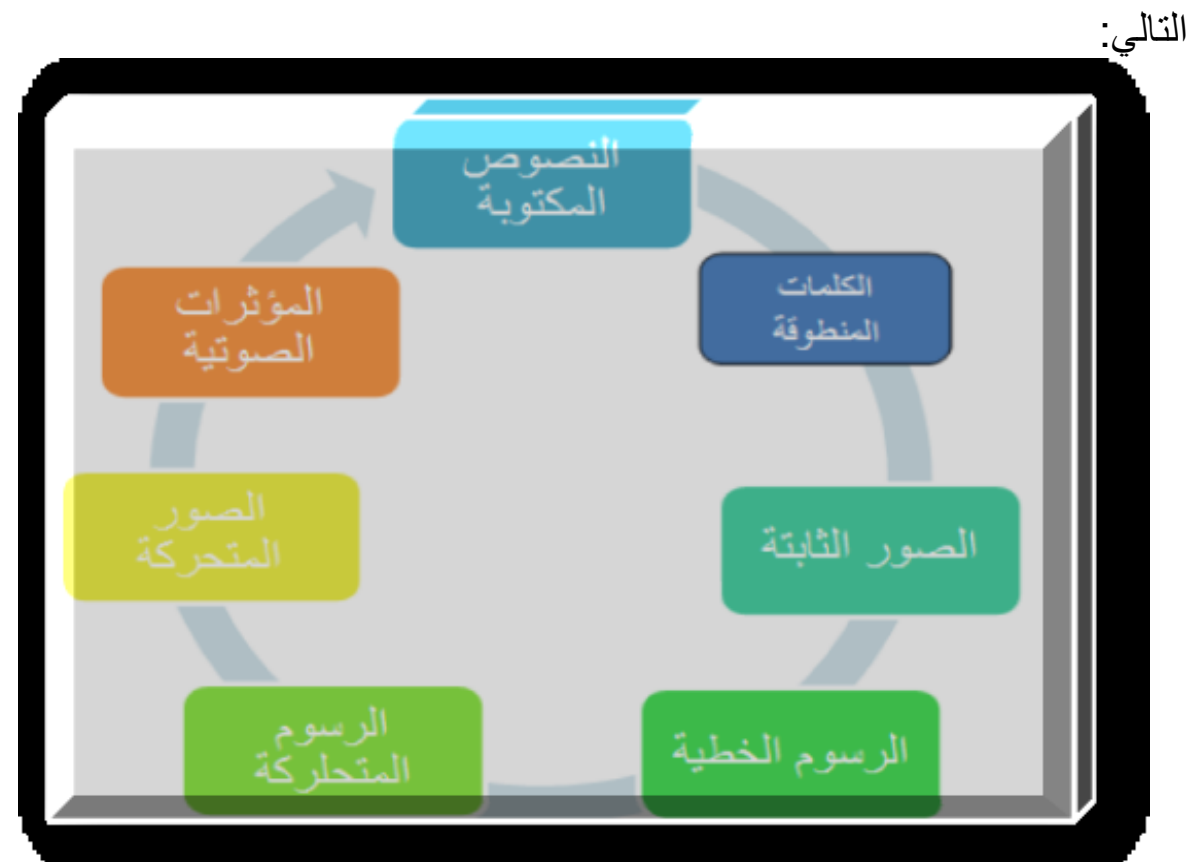

شكل (1): مكونات الوسائط المتعددة التفاعلية

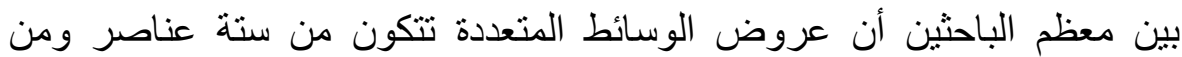

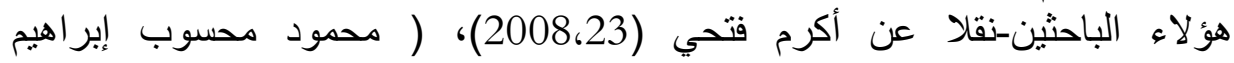
137-2002،22:

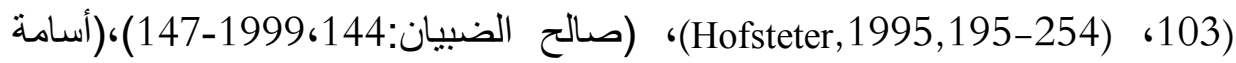
عبد الباسط:20،2002-30)؛( هاني محمد عبده:20، (2001-22)، (كمال زيتيون:

أو لا: النصوص المكتوبة Texts (Written Word)

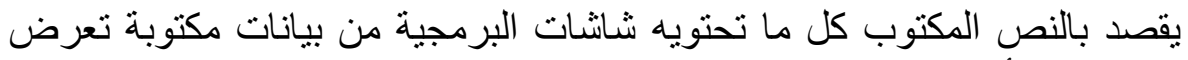

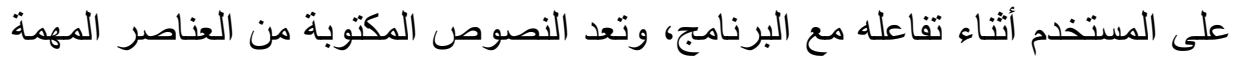
للوسائط المتعددة التفاعلية حيث يتم استخدامها في:

$$
\begin{aligned}
& \text { • كتابة العناوين الرئيسية والفرعية. } \\
& \text { • • القو ائم و المفاتيح. } \\
& \text { • توضيح الأفكار وشرح الدروس. }
\end{aligned}
$$




$$
\begin{aligned}
& \text { • تعريف المستخدم بأهداف البرنامج. } \\
& \text { شرح مكونات الصور و الرسوم. } \\
& \text { عرض إرشادات وتوجيهات للمتعلم. } \\
& \text { تقديم الاستجابة النصية. }
\end{aligned}
$$

وتنقسم النصوص في بر امج الوسائط المتعددة التفاعلية إلى:

أ- النصوص العادية Normal Text: و وهي نصوص خطية مكتوبة ليس بينها

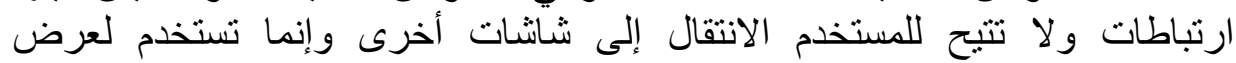

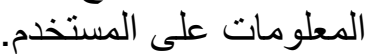

ب- النصوص الفائقة Hyper Text: وهي نصوص مكتوبة تعمل على تخزين وربط

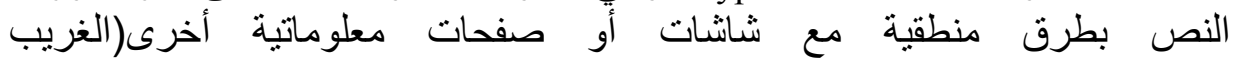
إسماعيل:187، (1801)

ثانبا: الصوت Sound تتتوع الأصوات التي توجد في برامج الوسائط المتعددة التفاعلية إلى:

1- اللغة المنطوقة (المسموعة) Spoken Words تتمثل في أحاديث مسموعة بلغة ما؛ مثل التعليقات الصوتية أو الإرشادية

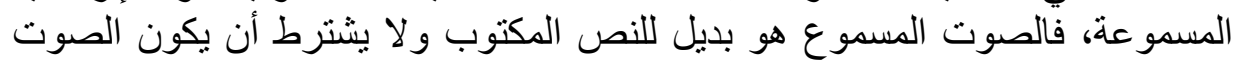

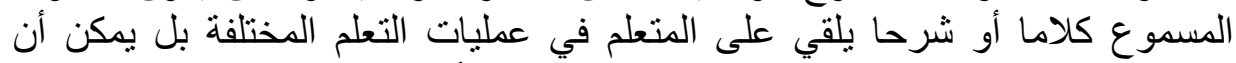

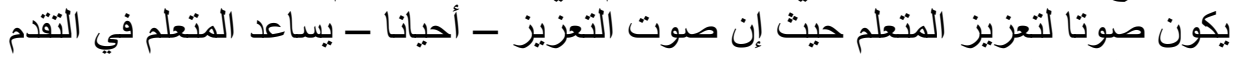
نحو عمليات التعليم و التعلم.

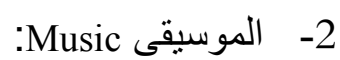

تعمل الموسيقى على جذب الانتباه وخلق نوع من الانفعال بين المتعلم والبرنامج

\section{3-المؤثر ات الموسيقية Music Effects:}

هي مؤثرات تعمل على جذب انتباه المتعلم نحو العرض كما أنها تأتي غالبا

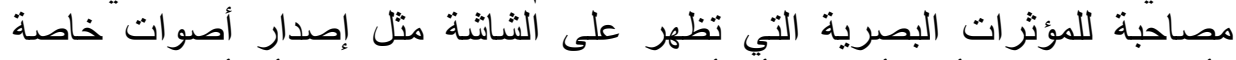
كأصوات الرياح، أو الأمطار، أو أصوات أظورات الحيوانات والطئة الطيور، أو أصوات أصوات الآلات 
يعرف (محمد عطية خميس:118،1993) الصورة الثابتة بأنها صور ثنابتة رقمية

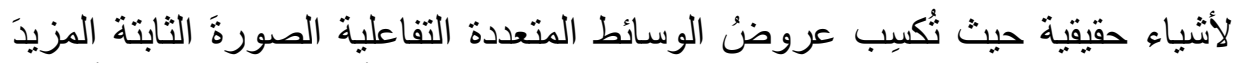

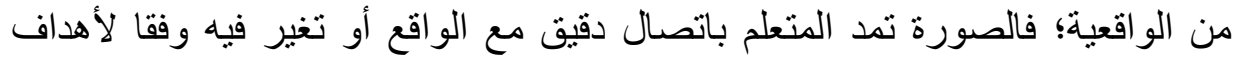

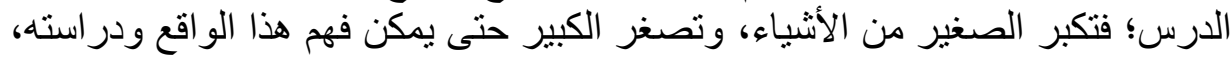

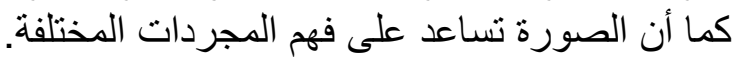

تتعدد مصادر الحصول على الصور الرقمية حيث يمكن الحصول عليها من

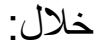

1- التصوير باستخدام الكاميرات الرقمية Digital Camera. 2- تحويل الصور الفوتوغرافية العادية إلى صور رقية رقية باستخدام الماسح الضوئي Scanners. 3- لقطات الفيديو و الرسوم المتحركة باستخدام بر امج معالجة الصور .

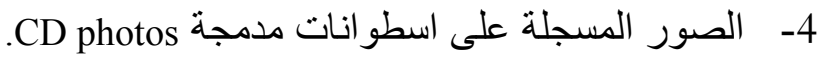
5- مواقع مكتبات الصور على الإنترنت.

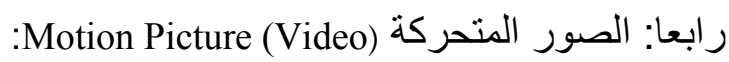
تظهر في صورة لقطات فيلمية متحركة سجلت بطريقة رقمية. الصورة الرقمية

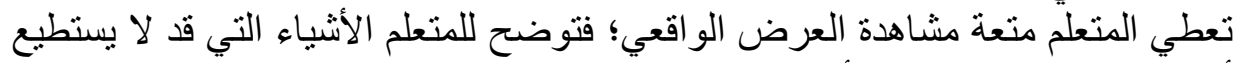
أن ير اها بطريقة مباثرة للأسباب التالية:

وقو عها في فترة زمنية بعيدة؛ منل الأحداث التاريخية والسياسية.

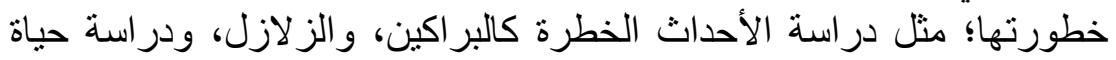
الحيو انات المتوحشة. بعدها المكاني؛ مثل در اسة الأماكن السياحية للبلدان المختلفة.

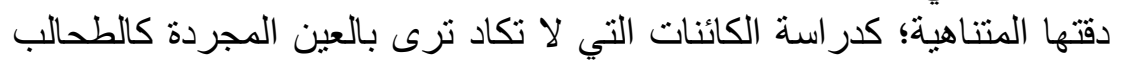

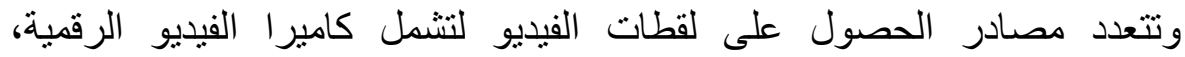
و عروض التلفزيون المسجلة، وبر امج إنتاج الفيديو، ومكتبات الفيديو لفيول على الإنترنت. خامسا: الرسوم الخطية Graphics: هي تعبير ات تكوينية بالخطوط و الأشكال (خالد محمود:78،2000) تظهر في

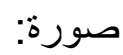
رسوم بيانية خطية أو دائرية أو بالأعمدة وغير ها من أشكال الرسوم البيانية 
لوحات أو خر ائط أو رموز مجردة أو رسوم توضيحية.

رسوم تنتج باستخدام برامج الصور مثرد مثل الرسوم ثنائية الأبعاد (2D) أو ثناثية

الأبعاد (3D). (3).

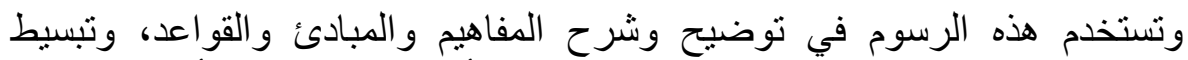

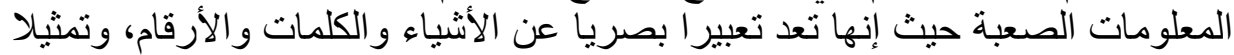

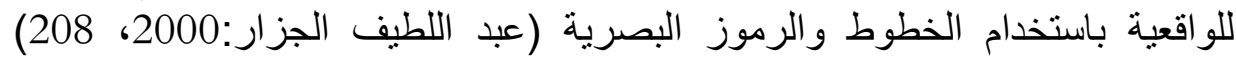
ويمكن إنتاج الرسوم الخطية باستخدام بر امج الصور والرسوم، أو إدخال هذه الرسوم الرماله

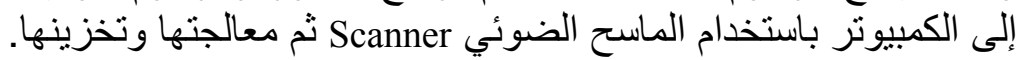

سادسا: الرسوم المتحركة Animation:

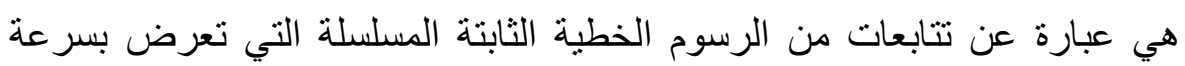
معينة وفي تتابعات محددة تبدو عند عرضها منا متحركة.

هناك نوعان من الرسوم المتحركة (هاني عبده: 2001، 22) كما هو مبين في الثكل

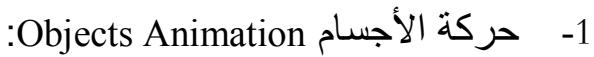

مثل تحريك الحروف و الأشكال داخل إطار الثاشة دون تغيير في شكلها.

حركة الإطار ات: Frames Animation:

حركة تتنج من سلسلة من الرسوم الخطية الثابتة التي تعرض بسر عة 24 إطارا في

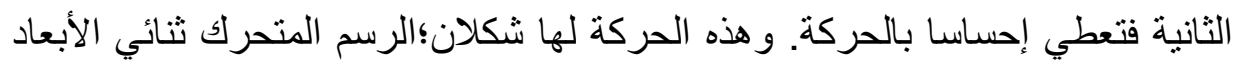
2D.Animation و الرسم المتحرك ثناثي الأبعاد التهاد 


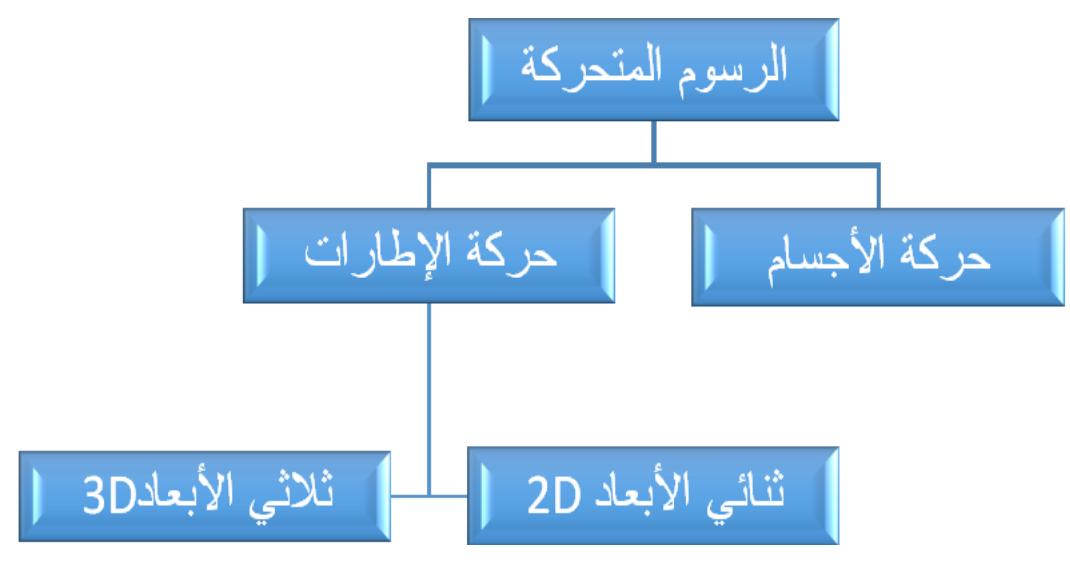

$$
\text { شكل (2) أنواع الرسوم المتحركة }
$$

:Merging - - - الاندماج

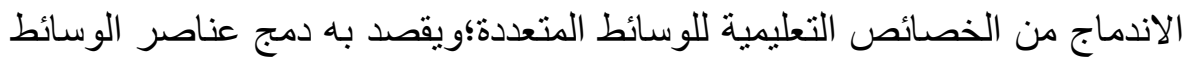

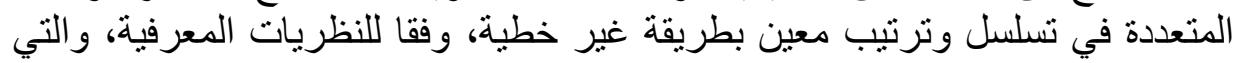

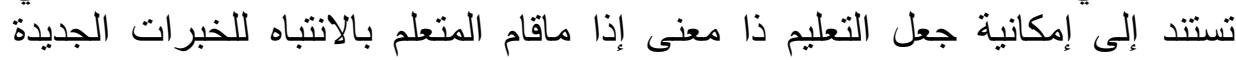

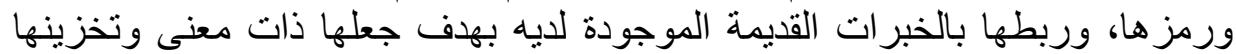

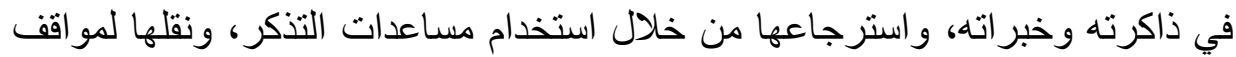

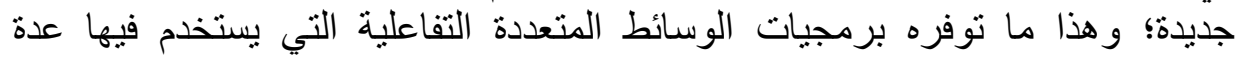

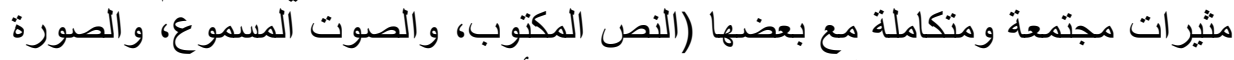

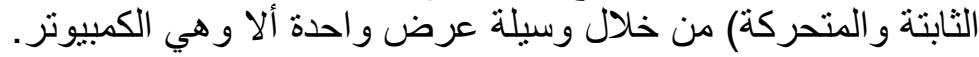

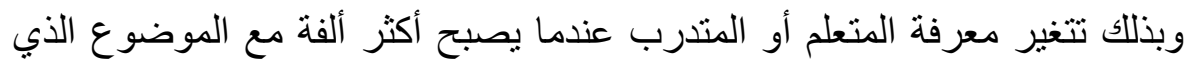

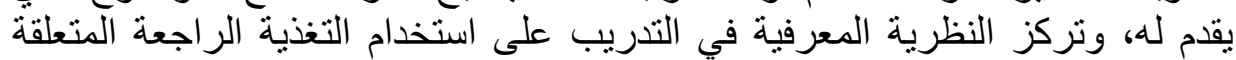

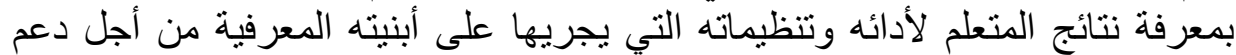
وتوجيه الروابط الذهنية.

من خلال العرض السابق لخصائص الوسائط المتعددة يمكن استخلاص الآتي:

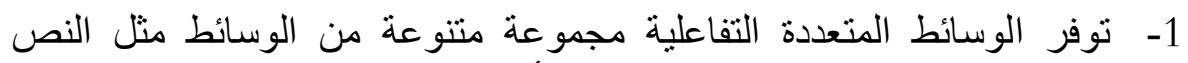

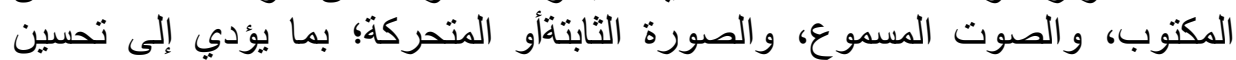
مستويات التعلم، وجذب انتباه المتعلم نحو الدرس.

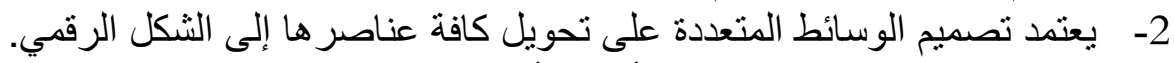

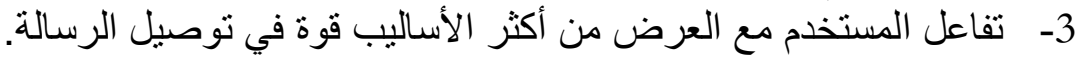


4- تُصمم الوسائط المتعددة التفاعلية، وتُخزن وتُعرض من خلال الكمبيوتر وتقنياته المتطورة.

5- يعتمد بناء الوسائط المتعددة على النظريات المعرفية؛ من خلال تجميع،

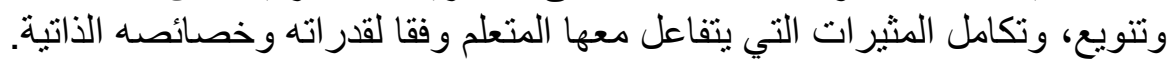

\section{معوقات استخدام الوسائط المتعددة في تعليم اللغة العربية:}

يشير (أكرم فتحي:50،51-2008) إلى أنه رغم المميزات و الخصائص التعليمية

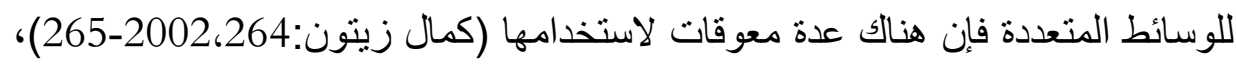
(صالح الضبيان:157،1999-158)، ويمكن تلخيصها في النقاط التالية:

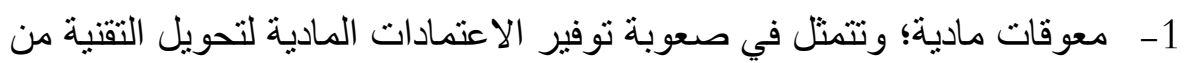
فكرة إلى إنتاج، بالإضافة إلى ارتفاع تكاليف متطلبات الوسائط المتعددة من أجهزة

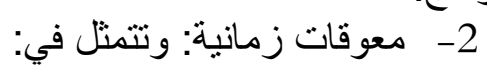

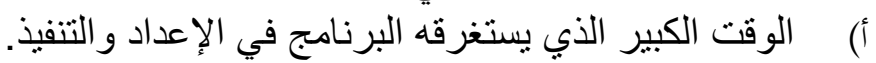

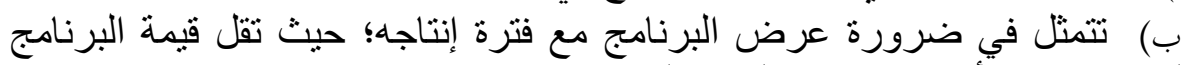
إذا لم يتم عرضها أو يستخدم في الوقت فئت المناسب.

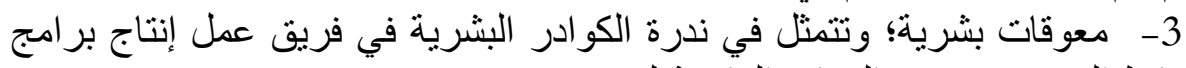

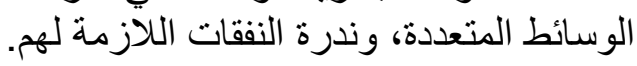

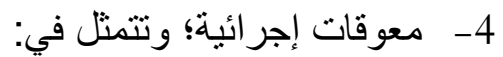

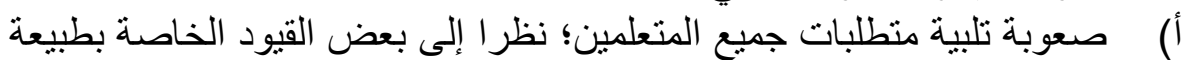

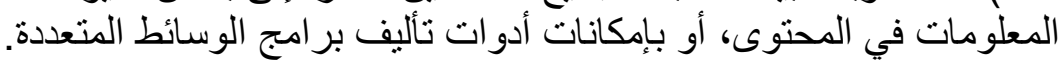

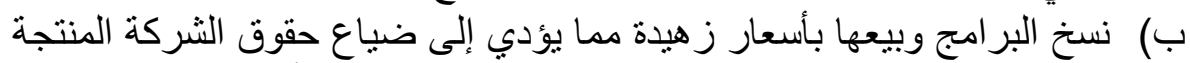

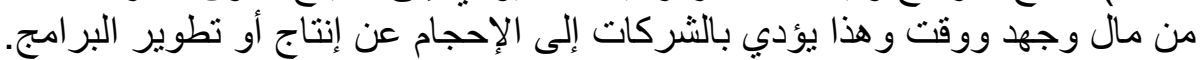

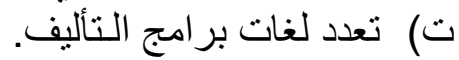
5- معوقات إنتاجية؛ وتتمثل في الجئ الجهد العلمي والعملي في اختيار، وتصميم،

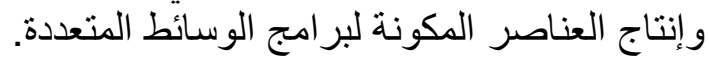

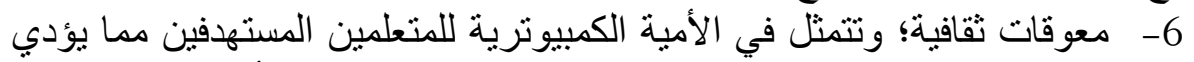

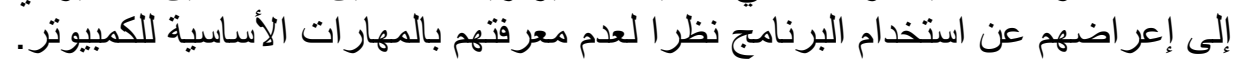

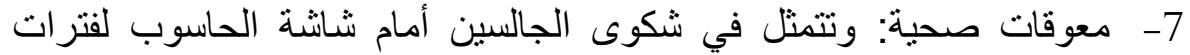
طويلة من بعض المشاكل الصحية.

المبحث الرابع: توظيف تكنولوجيا الوسائط المتعددة في تعلّيم المهارات اللغوية 


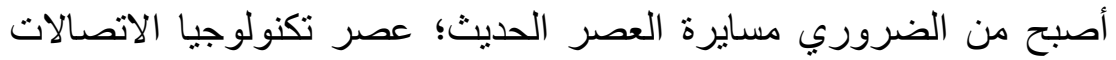

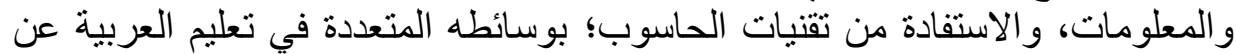

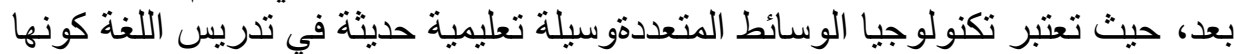

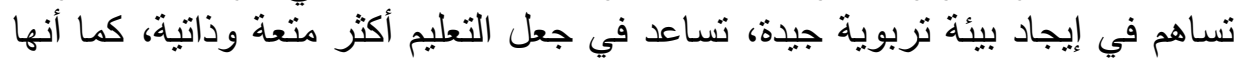

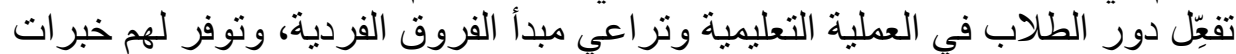

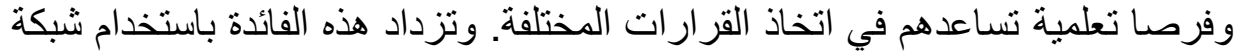
الإنترنت العالمية (خالدة شتت:2004،611). يعرف (أحمد العنزاوي:2008) التعليم

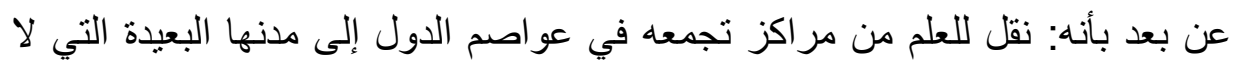

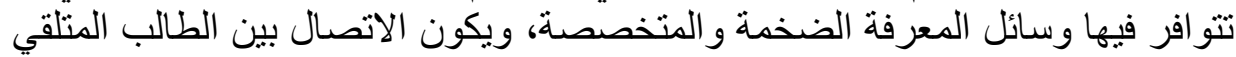

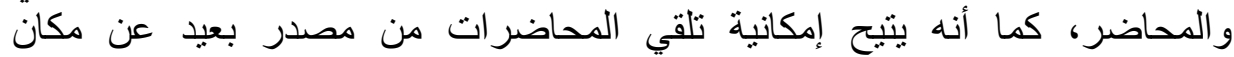

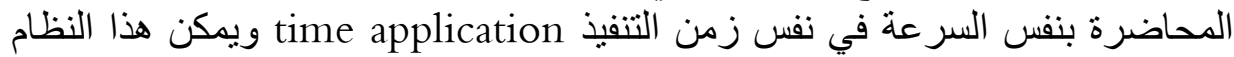
من بث المحاضرات الحية والمسجلة بكفاءة عالية ويطلق على هذه العملية أيضا

Internet-based Learning

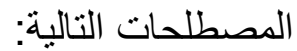

Distributed Learning

Computer-Mediated Communication

ترى المنظمة العربية للتربية والثقافة والعلوم (الاستراتيجية العربية للتعليم عن فئ بعد:37،2005) أن التعليم عن بعد هو نظام تعليمي يقوم على فكرة إيصال التئر المادة

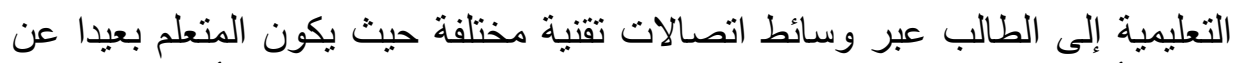

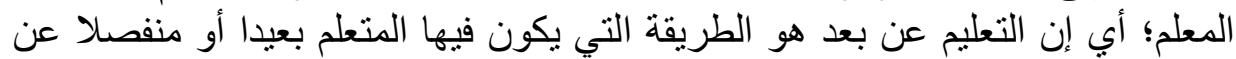

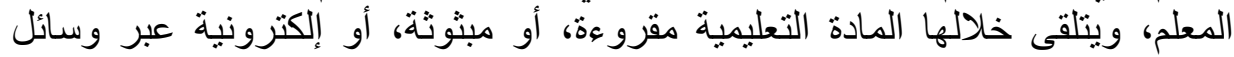
اتصال مختلفة. ولتعليم العربية عن بعد مبادئ أساسية تقوم عليها الفلسفة التربوية وتتلخص في النقاط التالية:

إتاحة الفرص التعليمية لكل الراغبين والقادرين على تعلم العربية دون حدود

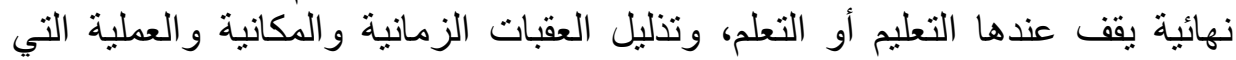
تعوق عملية التعلم. المرونة في التعامل بين أطر اف العملية التعليمية لتخطي الحواجز و المشكلات التي قد تنشأ بفعل النظام أو بفعل القائمين عليه. تنظيم موضوعات المنهج، وأساليب التقويم حسب علبه قدرات المتعلمين وظروفهم استقلالية المتعلمين وحريتهم في اختيار الوسائط التعليمية، وأنظمة التوصيل

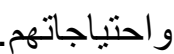
بصورة فردية حسب ظروفهم العملية وأماكن تو اجد هم. 


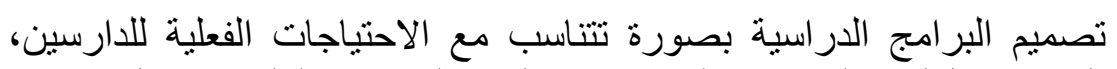
و اعتماد الدرجات العلمية التي تمنح لهم بعد معادلتها بالدرجات العلدية العية في المؤسسات

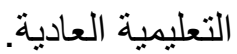

الإسهام في تحسين نظم التعليم التقليدية في مجالات البرامج الدراسية الأساسية و التكميلية والإضافية.

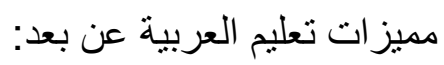

\section{لتعليم العربية عن بعد مزايا متعددة نذكر بعضا منها على التحو التالي:}

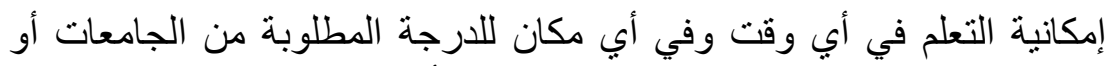

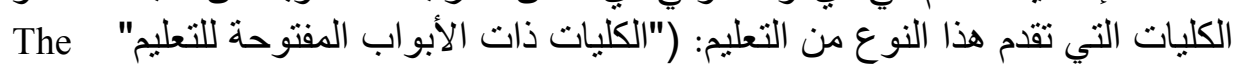
(never Close for Learning Collage (Learning Collage 24-hoursA Day

زيادة إمكانية الاتصال بين الطلاب فيما بينهم، وبين الطلاب و المؤسسة

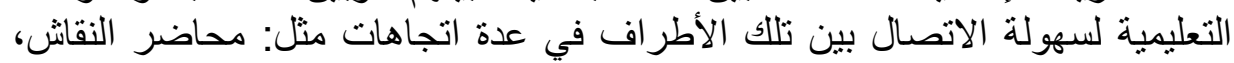

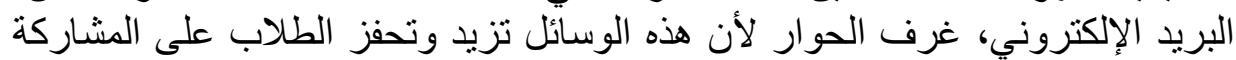
و التفاعل مع الموضونيو عات المطروحة. (هيفاء رضا:2002).

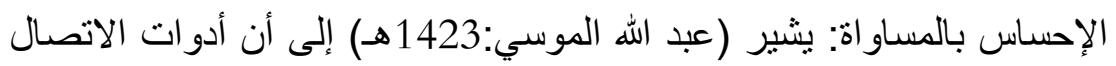

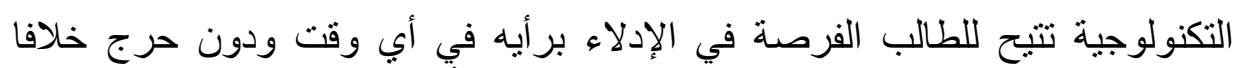

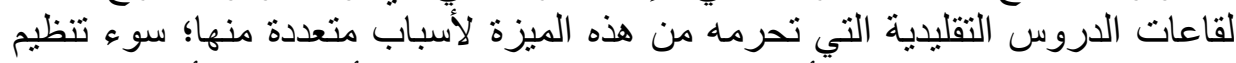

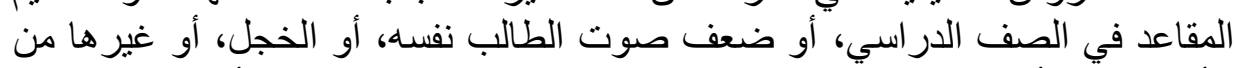

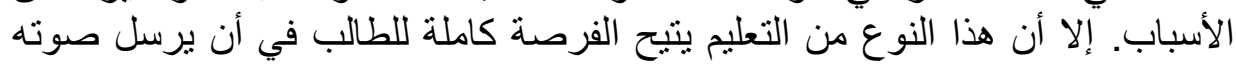

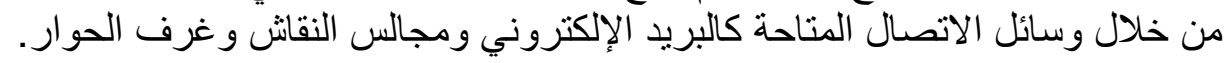

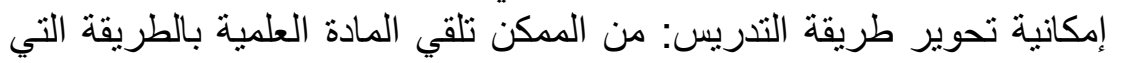

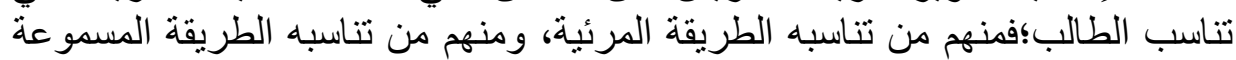

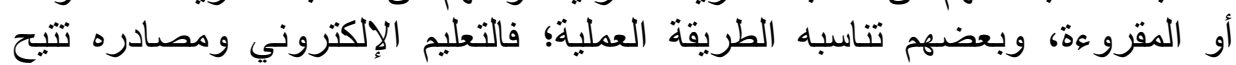
إمكانية تطبيق المصادر بطرق مختلفة وعديدة تسمح بالتحوير وفقا للطريقة التئي التئي يفضلها المتعلم.

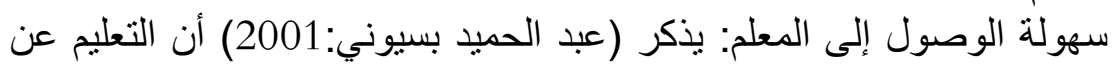

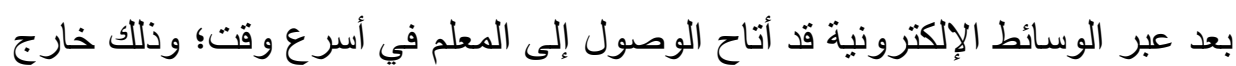

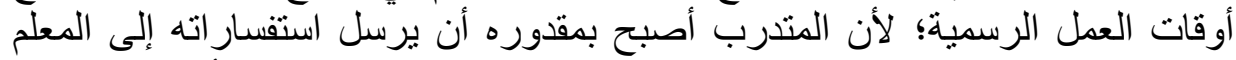

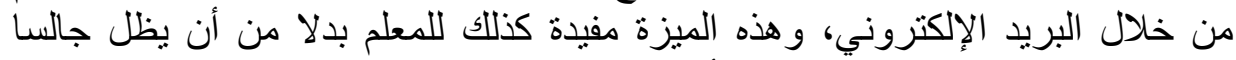

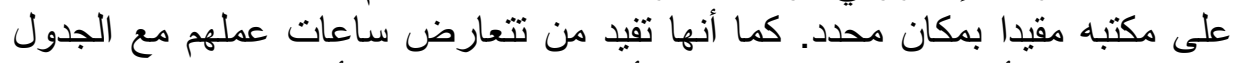
الدراسي للمعلم،أو عند وجود استفسار في أي وقت لفيد لا بحتمل التأجيل. 
وقد صُُمِمَت الكثير من البرمجيات والمواقع التعليمية المعتمدة على تكنولوجيا

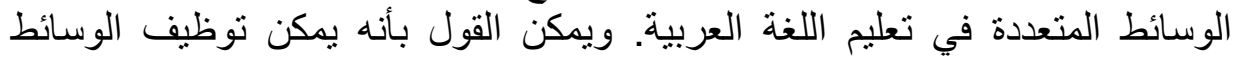
المتعددة التكنولوجية في تدريس اللغة في المجالات التالية:

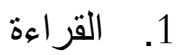

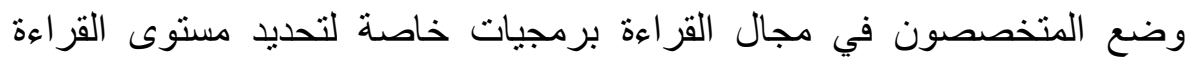

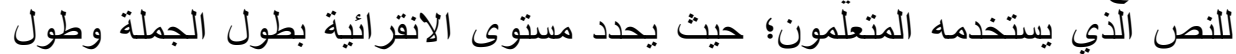

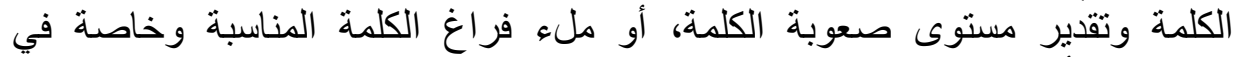

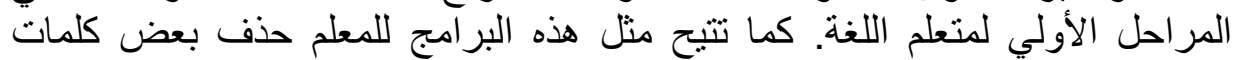

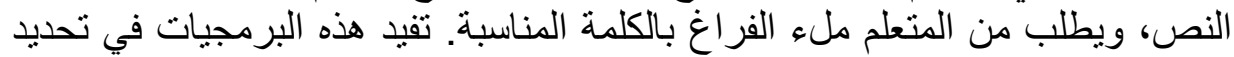

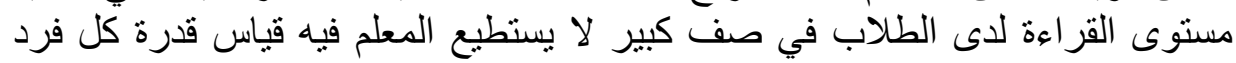

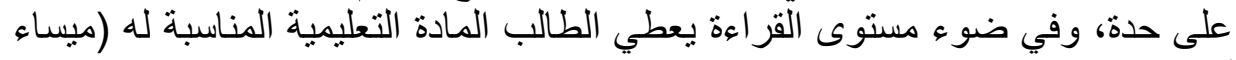
أبو شنب:2007).

يثير (إبراهيم عبد الوكيل الفار:54،54-2004) إلى إمكانية نو افر بعض البرامج

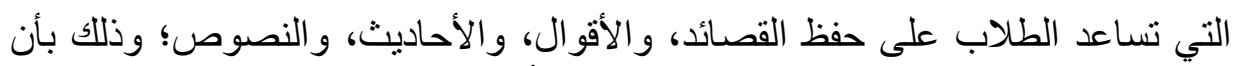

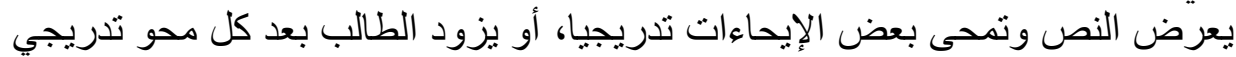

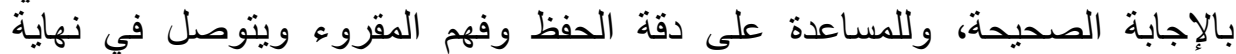

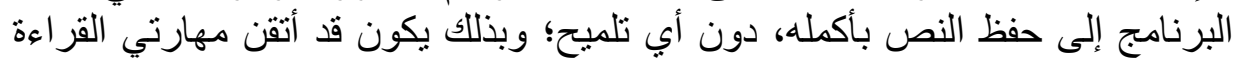

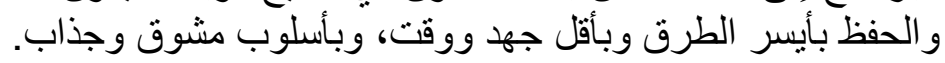

يرى الباحث أن هناك الكثير من المهارات التي يمكن تطوير ها في القراءة باستخدام الوسائط التكنولوجية التي يتيحها الحاسوب التئ على النحو التالي:

الاستيعاب Comprehension

هناك بعض البرمجيات المصممة بحيث بظهر نص إع على الثاشة ويلي ذلك أسئلة

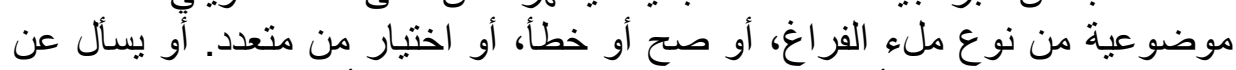

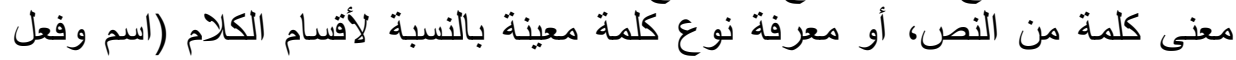
وحرف).

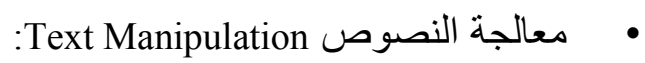

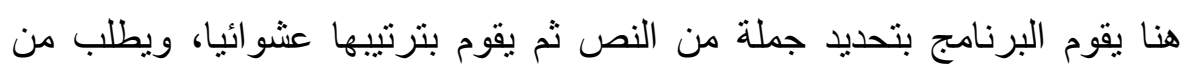

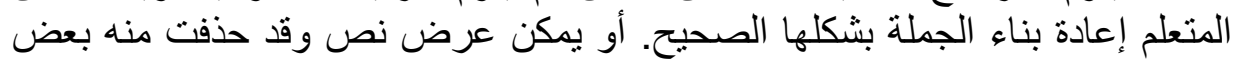

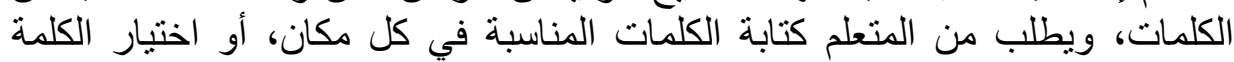

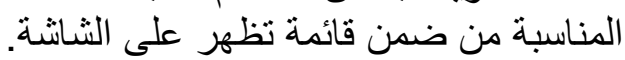

سرعة القراءة Reading Speed 
بمكن تطوير مهارة الطلاب في القراءة السريعة وتجنب القراءة كلمة ـ كلمة

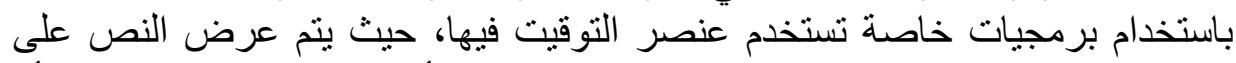

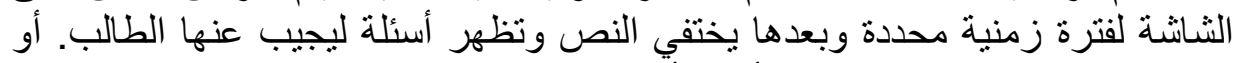
تتم العملية العكسية حيث تظهر الأسئلة أولا، تم يظهر النص بعد التهد ذلك. ومن ميزات هذه

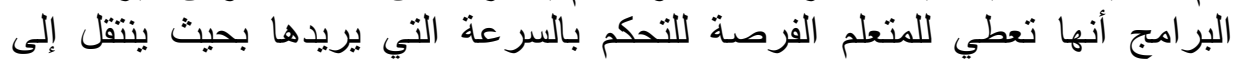
سر عات أعلى في حال تقدمه.

2. 2 - 2 - 2 الكتابة

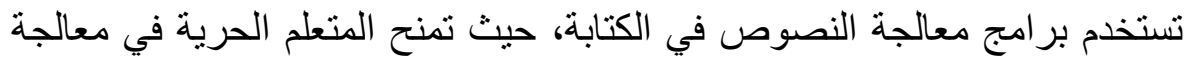

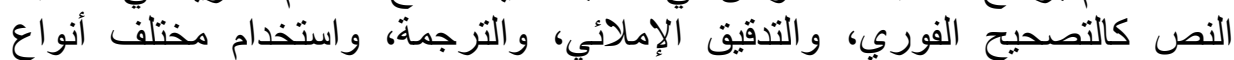

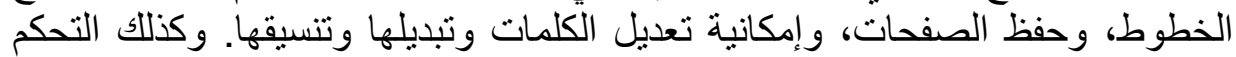

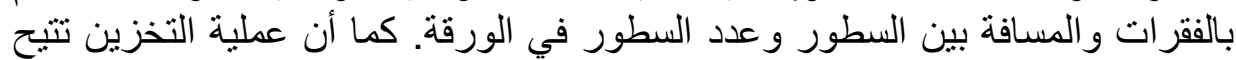
للمتعلم إعادة تفحص النص الذي كتبه و إجر اء التعديلات عليه و الاحتفاظ التهات بالنسخ القديمة منه وذللك لتفحص التعديلات العديدة التي تمت عليه.

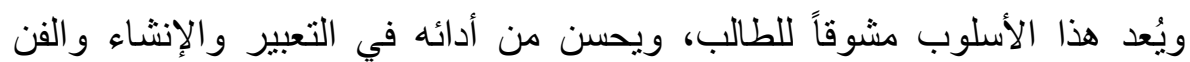
الجمالي، ويجعله أكثر إتقانا للغة والإملاء و أكثر دقة في القئ القضأيا النحوية.

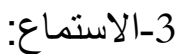

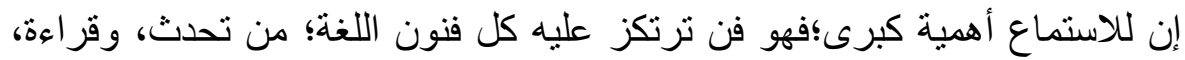

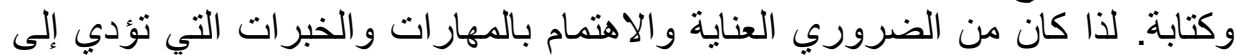

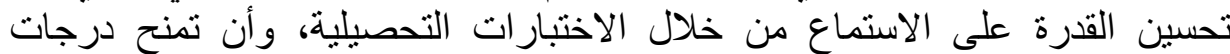

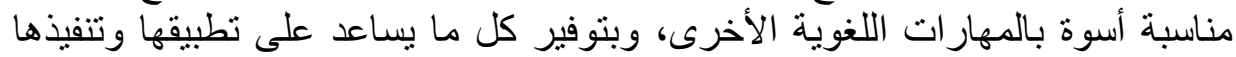
في الميدان التربوي من وسائط وأجهزة تسجيل ونئ وغير ذلك من الوسائط التعليمية (السليطي: 2006).

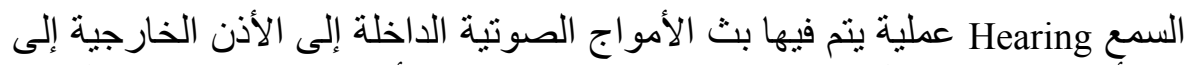

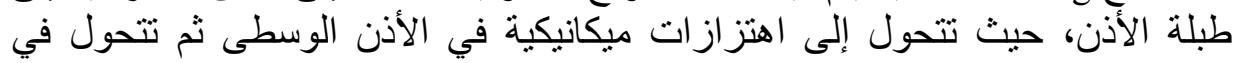

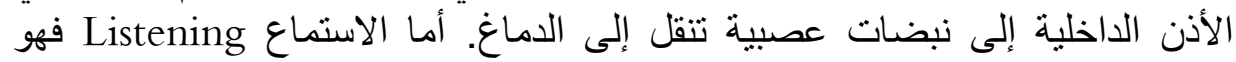

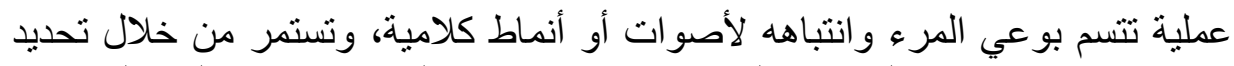

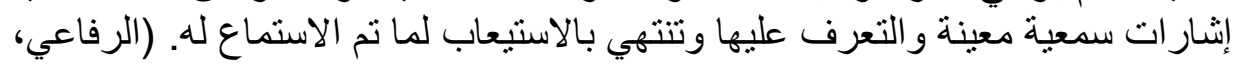

يحتاج المتعلم إلى نصوص متتوعة، ومستمدة من مواقف الاستماع، ومواده،

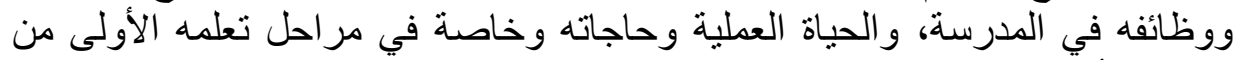

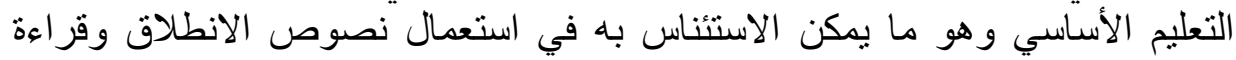


الاستماع وتكييفها، أو تطعيمها بمواقف ومواد أخرى للاستماع يمكن أن تحقت الأهداف

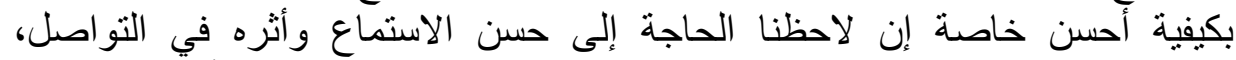

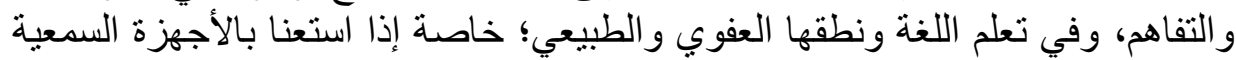

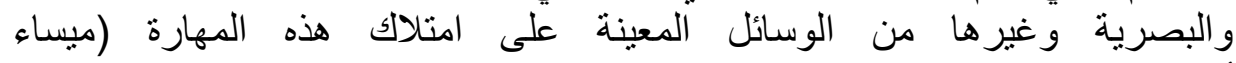
أبوشنب:2007، 108) (108).

يرى الباحث أن المواقع التعلمية على الثبكة الدولية للمعلومات بإمكانها تقديم مواد

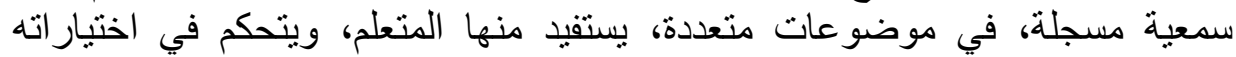
المختلفة حسب مستو اه وفهمه و تقدمه في البرنامج الدر اسي.

$$
\text { 4. المحادثة والتعبير الثفوي }
$$

لتنمية مهار ات التعبير الثفوي ينبغي أن تتاح للمتعلمين فرص كثيرة لمز اولة التعبير

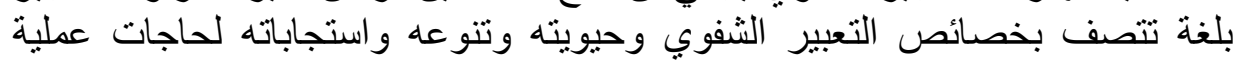
وطبيعية.

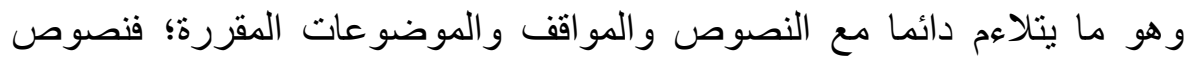

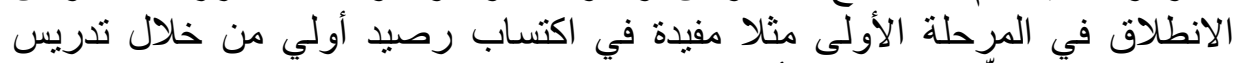

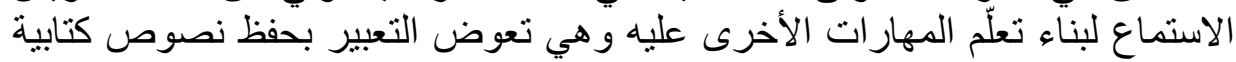

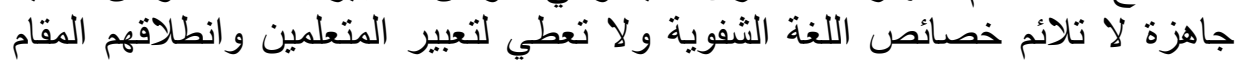
الأول الذي يخدم أهداف التعبير

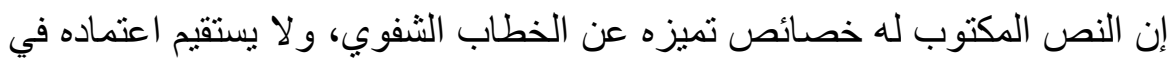

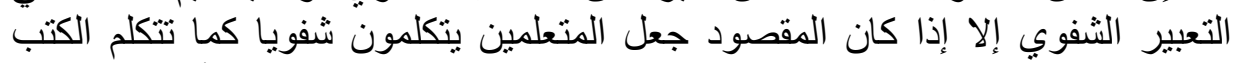

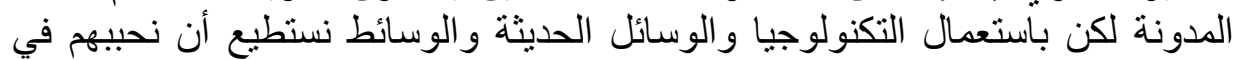

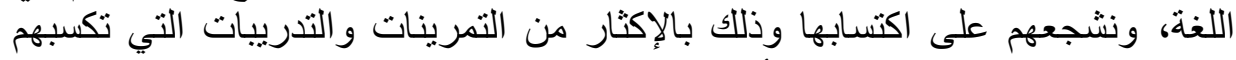

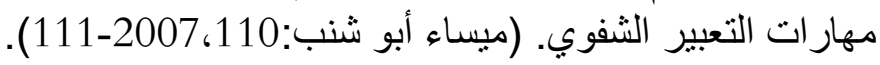

كما ينبغي علينا أن نشجعهم على مهارة التعبير الكتابي بالموازاة مع التعبير الثفوي التهاي

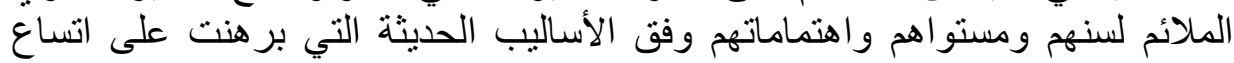
جدواها في مجالي التعبير الثفوي والهن والكتابي.

هنالك بعض البر امج التي تستخدم لتطوير مهارة التحدث لدى التى المتعلمين، حيث يقوم

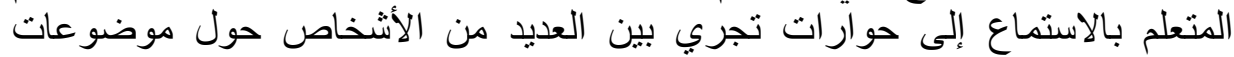

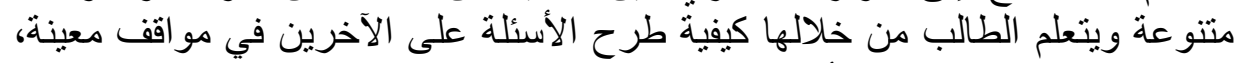
وكذلك كيف يرد على هذه الأسئلة إذا طرحت كلئه عليه. 


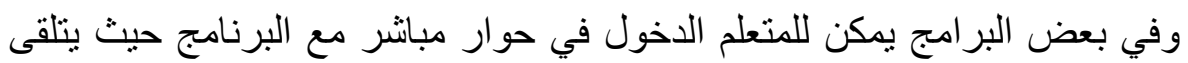

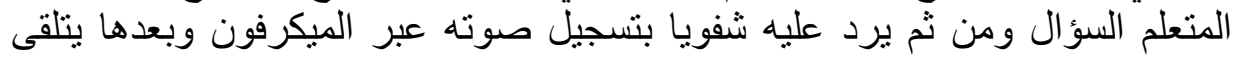
التغذية الر اجعة عن أدائه.

كما تتيح شبكة الإنترنت مواقع للتدرب على المحادثة بالنواصل مع الطناب

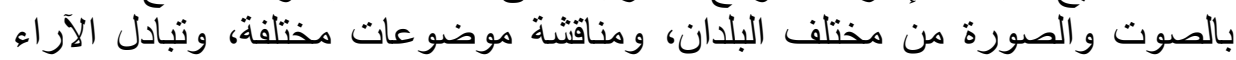

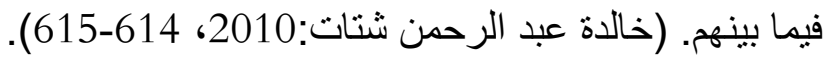

\section{المبحث الخامس: (المدرسة العربية الإكترونية) نموذج لتوظيفة التوبة الوسائط} التكنولوجية للحاسوب في تعليم العربية عن بعد من خلامل الإنل الثبكة الدولية.

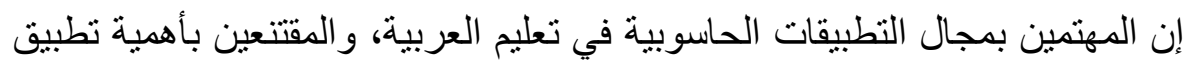

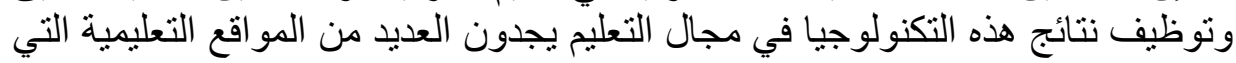

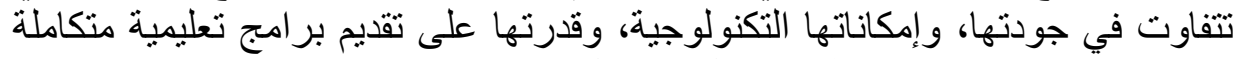

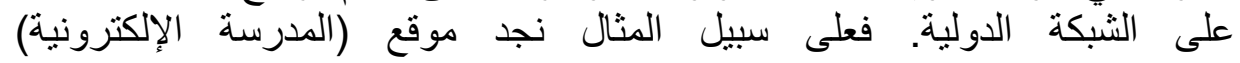
(www.schoolarabia.net) الثبكة الدولية. نجد ضمن هذه المقررات مقرر اللغة العربية الذي يقدم إلكترونيا لكل

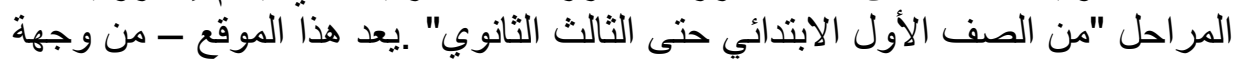

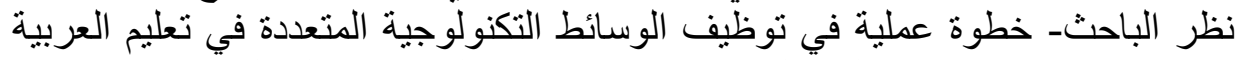

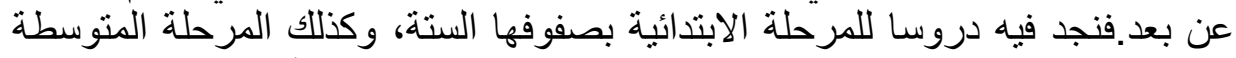

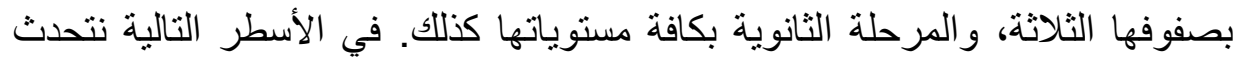

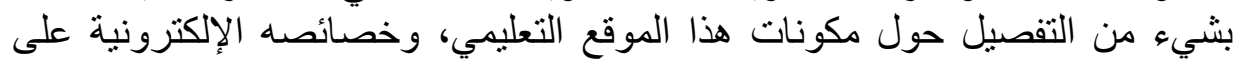
النحو التالي: التي:

المرحلة الابتدائية: تتكون هذه المرحلة من ستة مستويات؛ يقدم في المستوى الأول

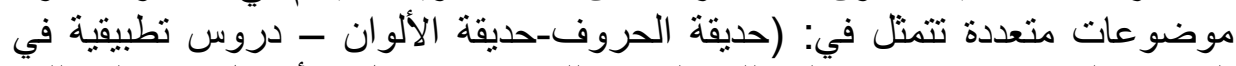

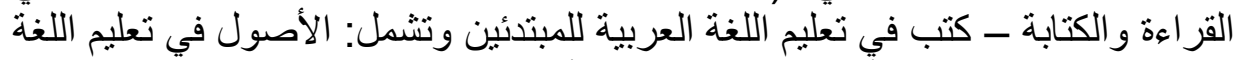

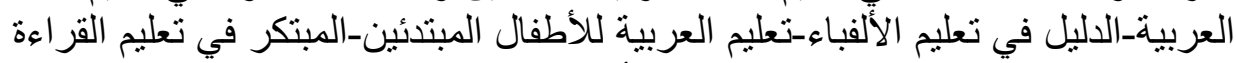

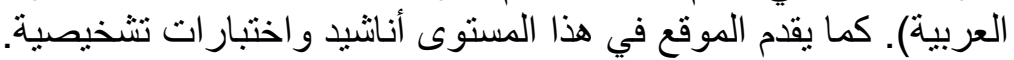

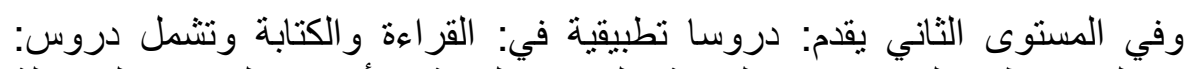

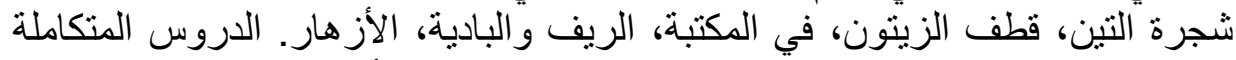

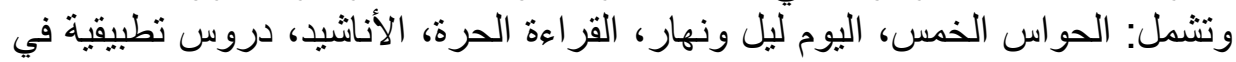
التعبير و المحادثة، اختبار ات تشخيصية.

وفي المستوى الثالث: يقدم الموقع عدة موضوعات منوعة الاتهة ونتثمل: القصص،

الأناشيد والمحفوظات، الدروس المتكاملة، الدروس التطبيقة موفية، الاختبار ات تشخيصية. 


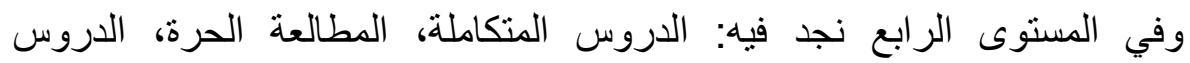

$$
\text { التطبيقية، دروس في الإملاء، النحو الواضعن فئح، تدريبات لغوية. }
$$

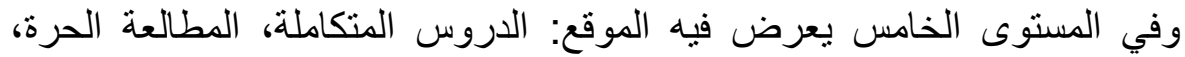

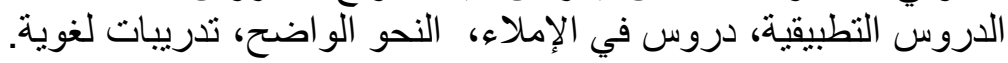

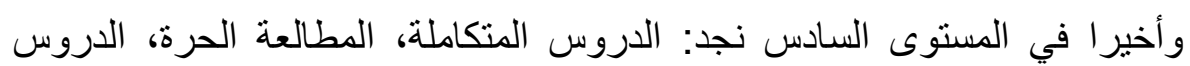

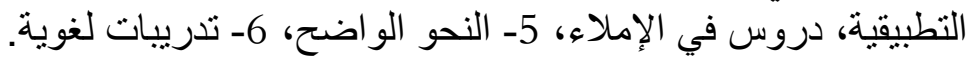

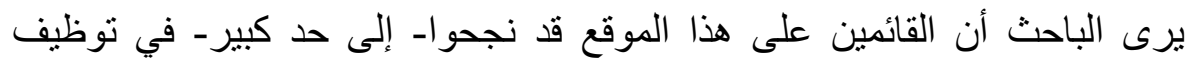

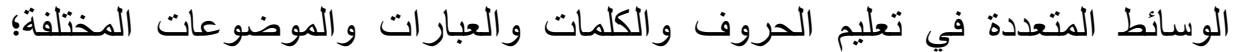

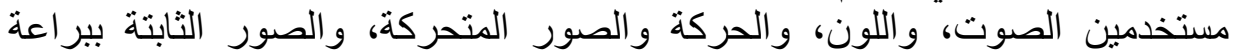

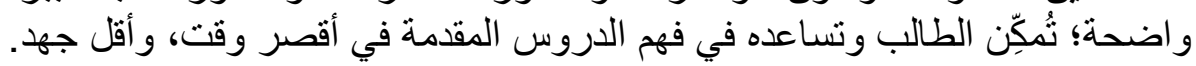




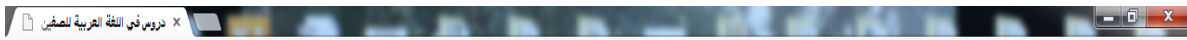

$\leftarrow \rightarrow$ C [ www.schoolarabianettasasaia/duroos____/arabimain.htm

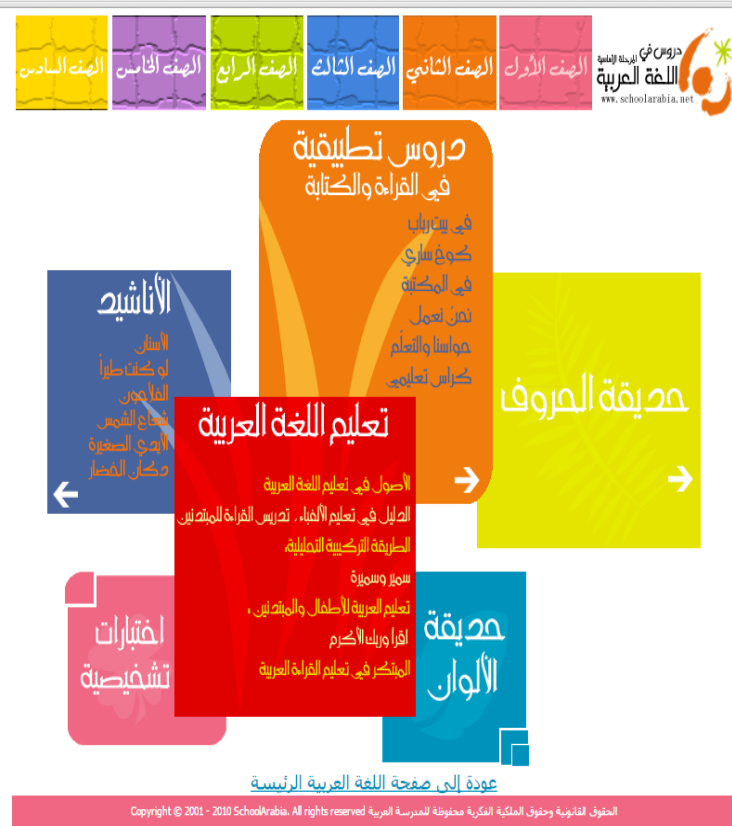

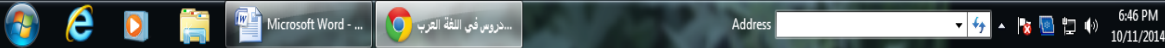

شكل يوضح عناصر المادة التعليمية المقدة للمستوى الأول على موقع schoolarabia.com

هذا الثكل يمثل الواجهة الرئيسية لصفحة المستوى الأول على الموقع وتضم ـكما

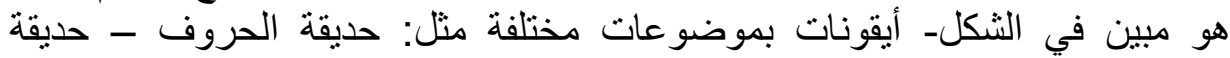
الألو ان - أناشيد - دروسا تطبيقة- نصوص خاصة بالقر اءة من كتب مختارة واخير التهات

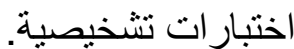


زكي أبو النصر البغدادي

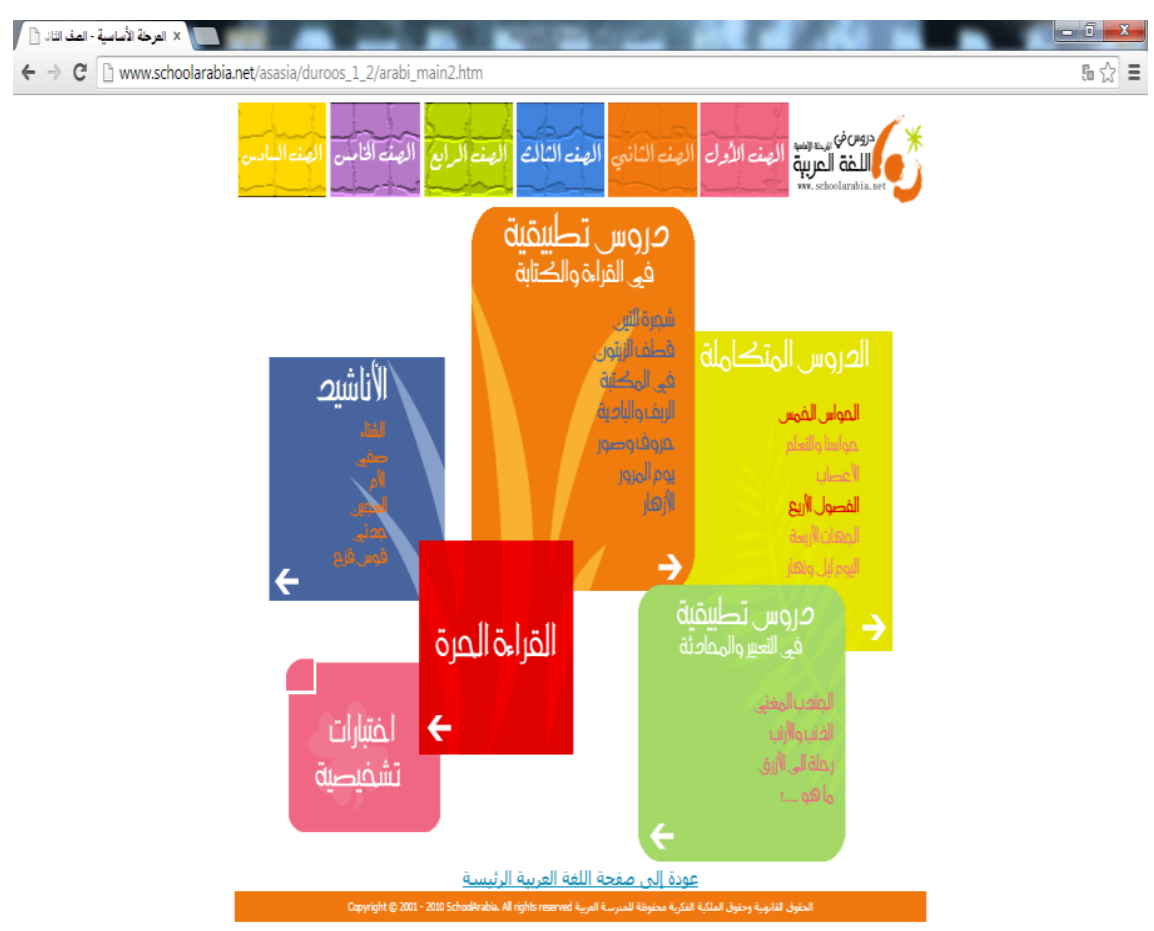

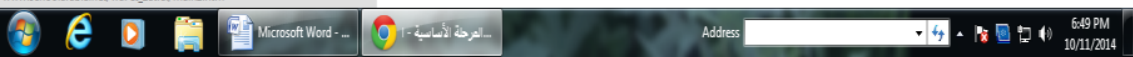

شكل يوضح عناصر المادة التعليمية المقدمة للمستوى الثاني على موقع schoolarabia.com

هذا الثكل يمثل الواجهة الرئيسية لصفحة المستوى الثاني على الموقع وتضم ـكما هو مبين في الثكل- أيقونات بموضوعات الثنات مختلفة مثل: دروس تطبيقية في التعبير

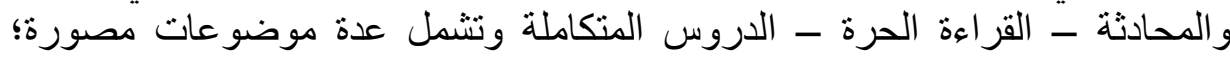
استخدم فيها وسائط تكنولوجية متعددة - دروسا تطبية الخيقية في القر اعة و الكتابة ـ أناثشيد؛ وأخير ا اختبار ات نتخيصية. 


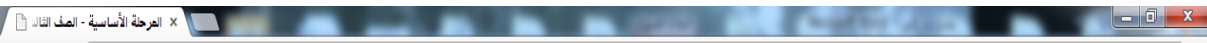

$\leftrightarrow$ C [〕 www.schoolarabia.net/asaia/duroos_____/arabi_main.htm

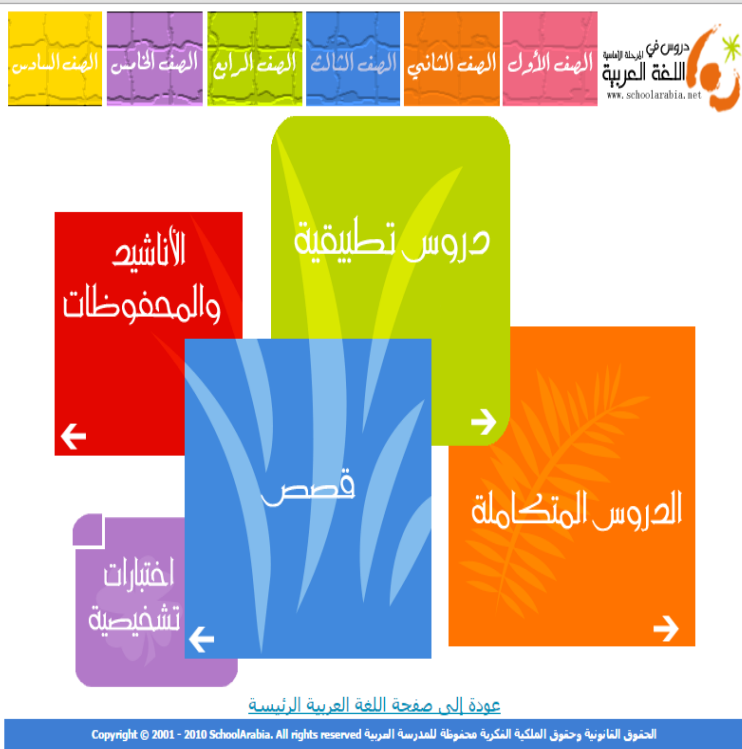

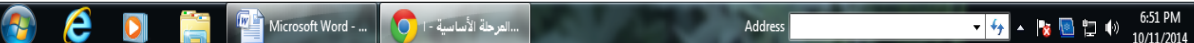

شكل يوضح عناصر المادة التعليمية المقدمة للمستوى الثالث على موقع schoolarabia.com

هذا الثكل يمثل الواجهة الرئيسية لصفحة المستوى الثالث على الموقع وتضم ـكما

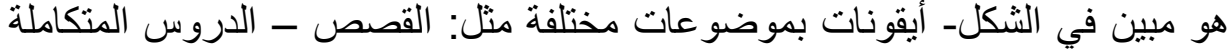
- الدروس التطبيقية- الأناشيد والمحفوظات وأخير ا؛ اختبار ات تشخيصية.

نلاحظ من خلال متابعة مثل هذه المواقع أنها تساعد الطلاب؛ لاسيما في الصفوف الطاب

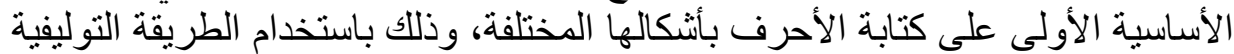

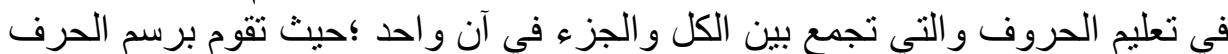

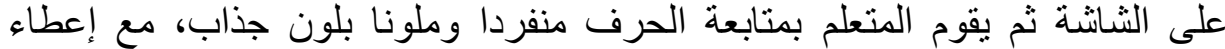

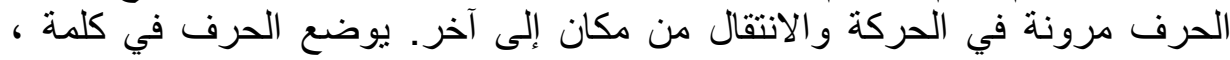




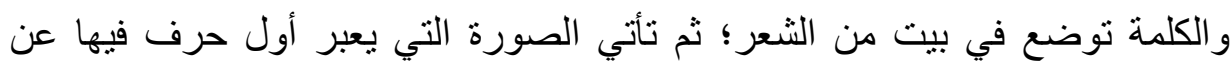

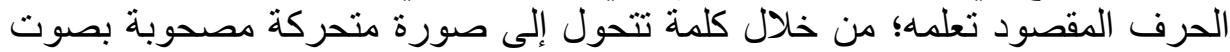
مسموع يمكن للمتعلم تكرار سماعه أكثر من مرة. كما هو هول مبين في الثكل التالي:

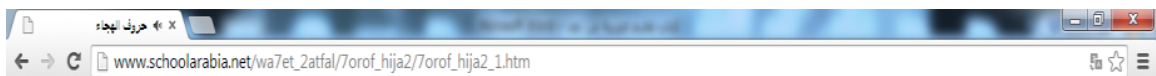

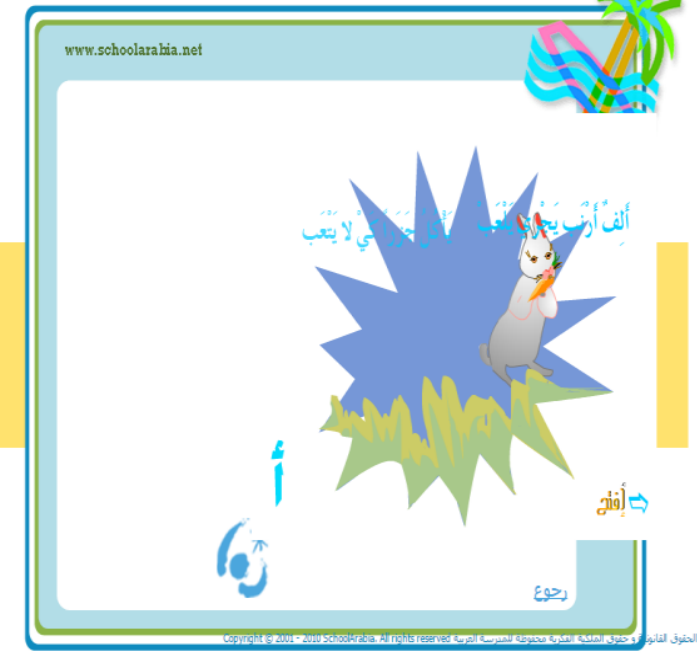

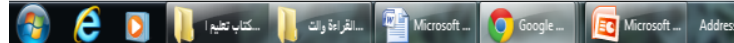

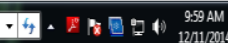

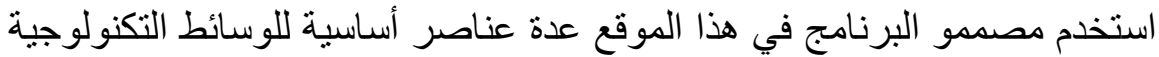

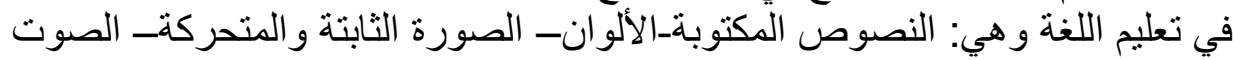

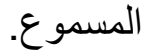

يقوم المتعلم باستخدام حواسه المختلفة؛ (السمعية والبصرية) في تعليم اللغة

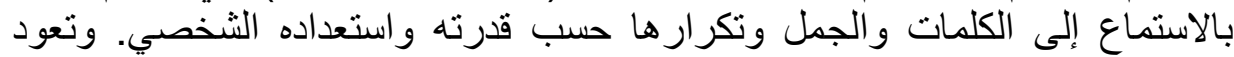

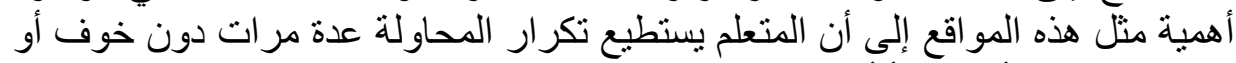
خجل من البطء أو الخطأ أمام الزملاء. الزعاء المعاء 


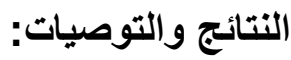

خلص البحث إلى عدد من النتائج والتوصيات على النحو التالي:

أولا النتائج:

لتعليم العربية عن بعد مز ايا متعددة؛ من أهمها:

إتاحة الفرصة في تعلم اللغة العربية لأكبر عدد من المتعلمين حول العالم من

خلال شبكة المعلومات الدولية.

إمكانية التعلم في أي وقات المانة وفي أبي مكان.

زيادة إمكانية الاتصال بين الطيان وفي الطلاب فيما بينهم، وبين الطلاب و المؤسسة

التعليمية لسهولة الاتصال بين تلك الأطران افت فين الطي عدة اتجاهات.

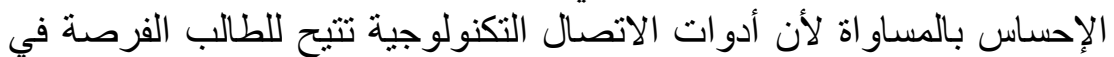

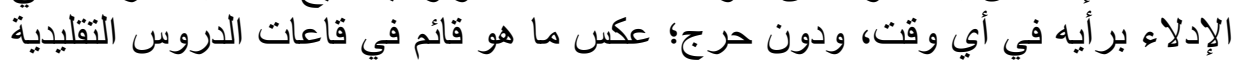

التي تحرمه من هذه الميزة.

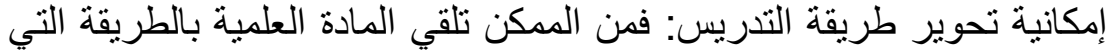

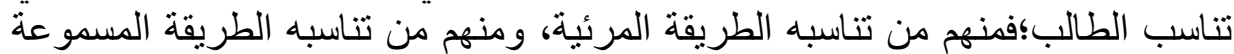

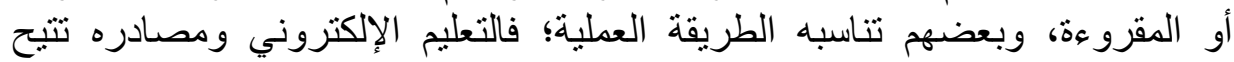
إمكانية تطبيق المصادر بطرق مختلفة وعديدة تسمح بالتحوير وفقا للطريقة التي التئي

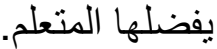

كما خلص البحث أيضا إلى ضرورة استخدام الوسائط المتعددة التكنولوجية في تعليم

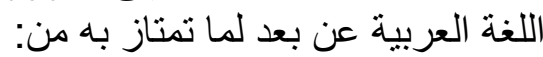

تسهيل لعملية الحصول على المعلومات عن طريق استثارة عدد أكبر من

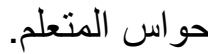

توفر للمتعلم الوقت الكافي ليعمل حسب سر عته الخاصة دون الإحساس بضغط

$$
\text { تزود المتعلم بالتغذية الر اجعة الفورية. }
$$

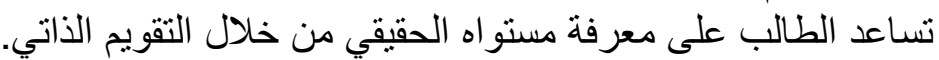

إن ثورة المعلومات والاتصالات قد أحدثت تحولات هائلة في مجال التعليم؛ فبعدما

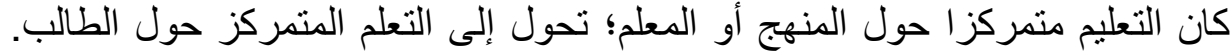

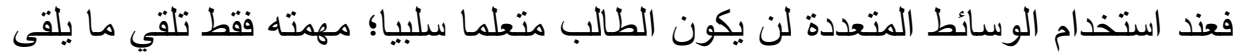

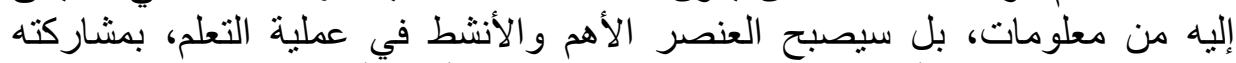

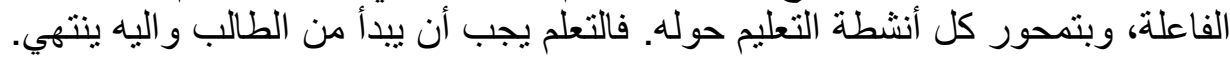


الأول: التحول من الأسلوب الإلقائي ذي الاتجاه الواحد إلى أساليب تدريسية

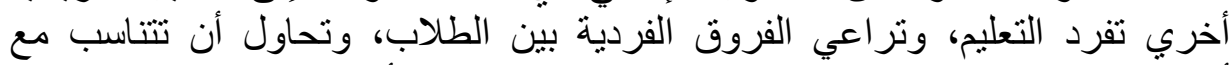

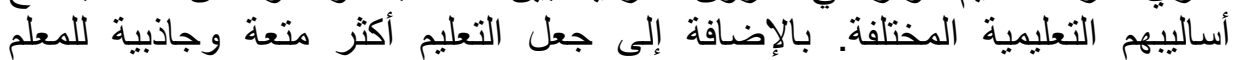

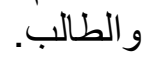

الثاني: التحول من التدريس الذي يركز على الحفظ أو الاستظهار فقط؛ إلى الفهم و التطبيق، وتعلم مهار ات التفكير و التعلم الذاتي. لأني.

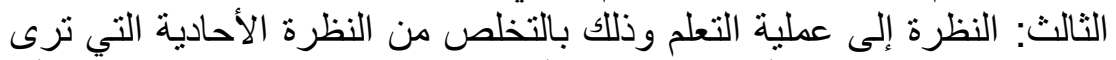

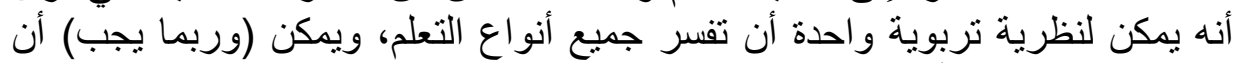
تنطلق منها جميع الأنشطة التدريسية بدةًا من النظرة النظرة السلوكية الميكانيكية الضيقة إلى الى الى

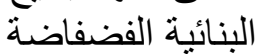

عند استخدام الوسائط المتعددة في تعليم العربية؛ تتغير أساليب التدريس

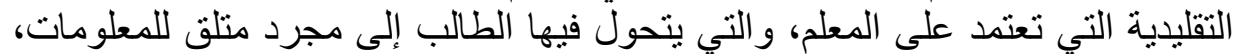

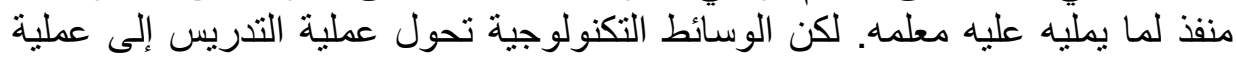

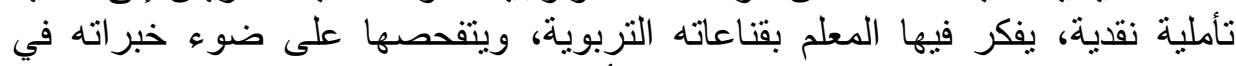

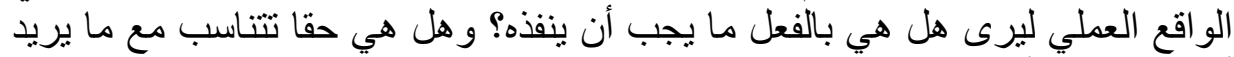

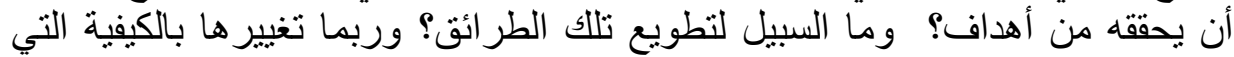

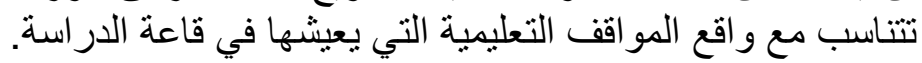
ثانيا: التوصيات: بناءً على النتائج التي توصل إليها الباحث يمكن تقديم عدة توصيات على النحو

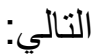

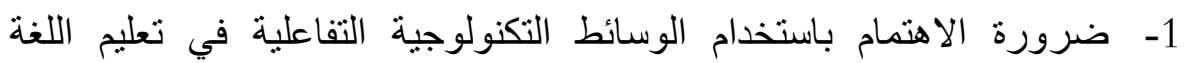

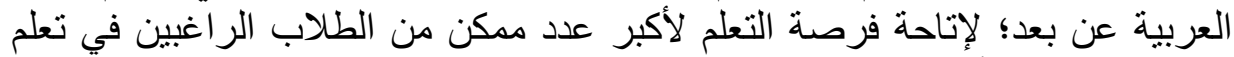

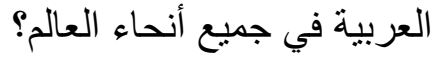

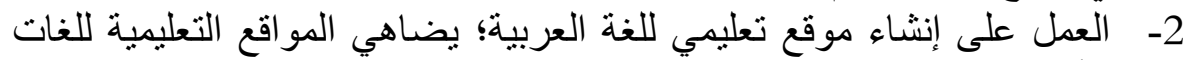

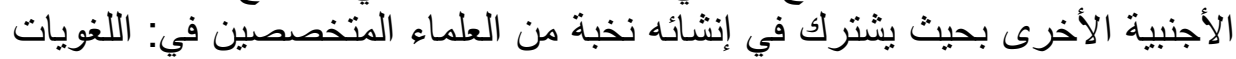

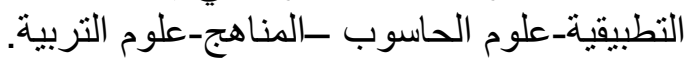

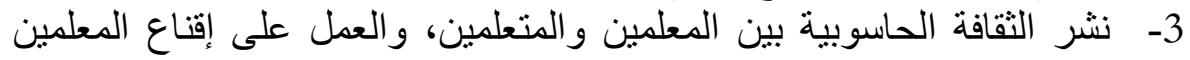

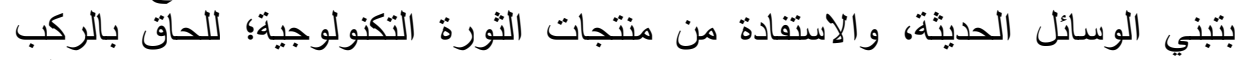

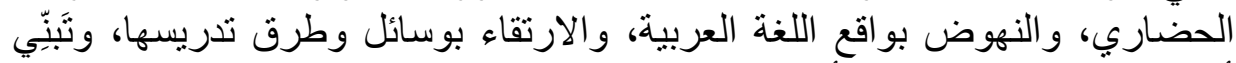

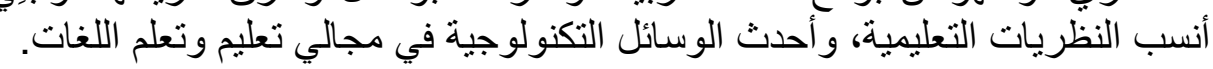


- ـ أحمد سالم: المواد والأجهزة التعليمية في منظومة تكنولوجيا التعليم، دار الزهراء،

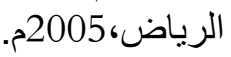
- ـ أحمد سالم: تكنولوجيا التعليم و التعليم الإلكتروني، الرياض، مكتبة الرشد، 2004م.

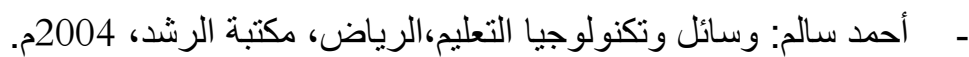

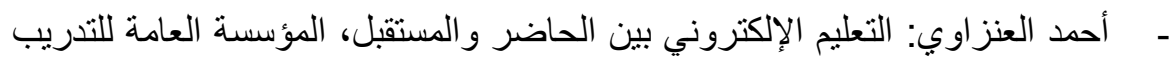
التقني و المهني، 2008 2008.

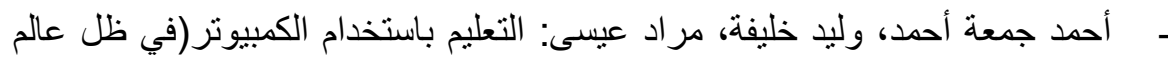

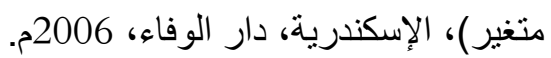
أكرم فتحي مصطفى:الوسائط المتعددة التفاعلية.رؤية تعليمية في التعلم عبر برمجيات الإنات

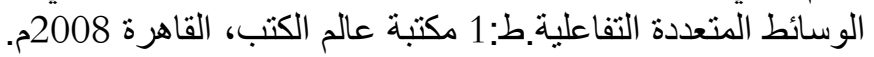
أسامة الحسيني: الثبكة الكمبيوترية العالمية، القاهرة، مكتبة ابن سينا، 1997م.

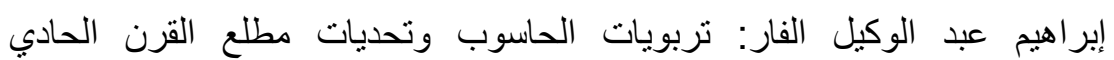
و العشرين،القاهرة، دار الفكر العربي، 2004 الفئ

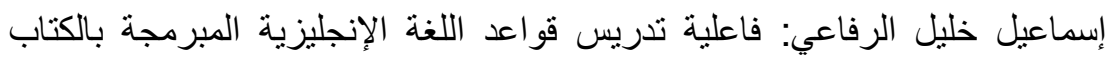

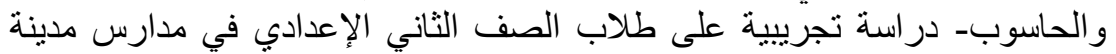

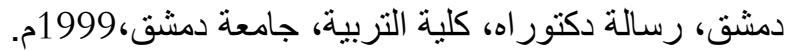

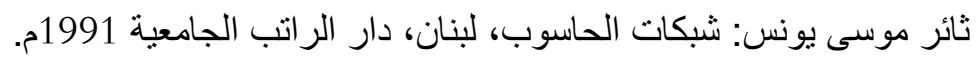

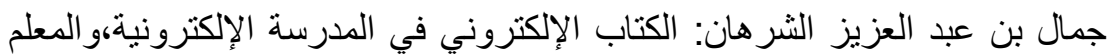

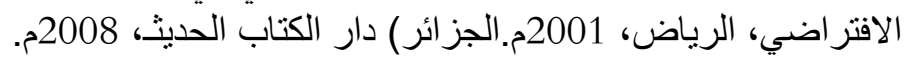

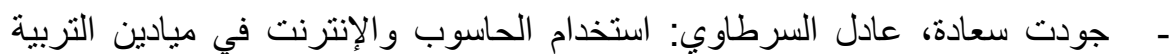

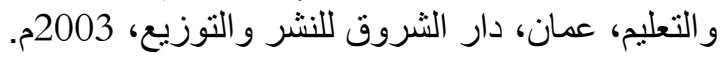

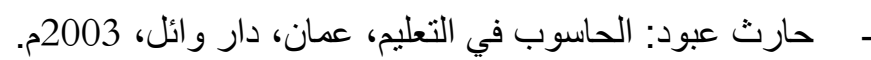

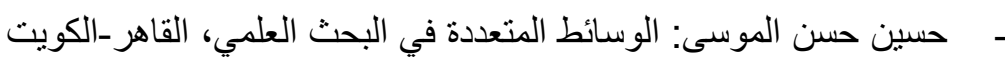

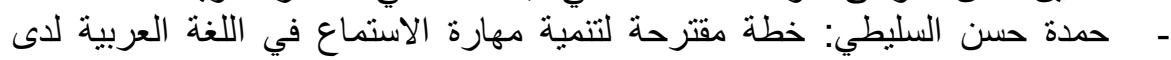

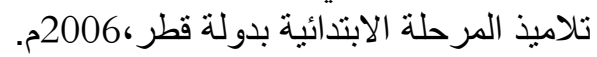
خالد محمد فرجون: الوسائط المتعددة بين التنظير و التطبيق، الكوبيت، مكتبة الفلاح

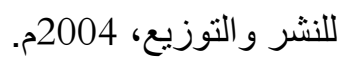
خالد السعود: تكنولوجيا ووسائل التعليم وفاعليتها، مكتبة المجتمع العربي للنشر و التوزيع، 2009م.

خالد محمود أحمد:أثر العلاقات البنائية في برامج الكمبيوتر متعددة الوسائل على فئى

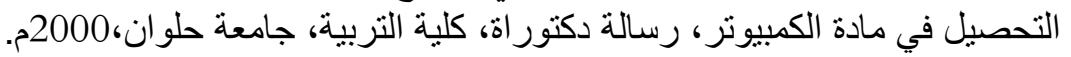

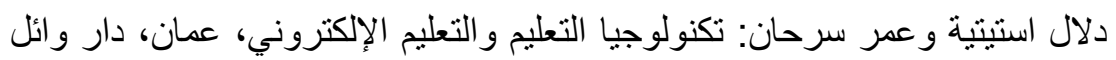

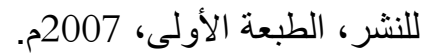


- - ـ رائدة خليل: تكنولوجيا التعليم، عمان، الأردن، مكتبة المجنمع العربي للنشر

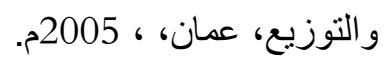

- ربحي عليان ومحمد الدبس: وسائل الاتصال وتكنولوجيا التعليم، دار صفاء للنشر و التوزيع عمان، 2004ميان ومدئ.

- - زينب محمد أمين:إثكاليات حول تكنولوجيا التعليم،المنيا دار الهدى للنشر و التوزيع،2000م.

- سعيد إسماعيل علي وهناء عودة خضري أحمد: الأسس التربوية للتعليم الإلكتروني، القاهرة، عالم الكتب، 2008م. 2008.

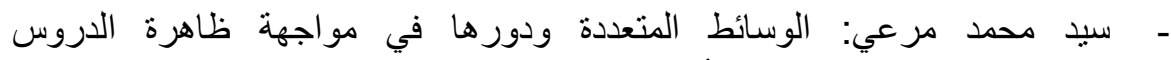
الخصوصية، القاهرة، مكتبة الأنجلو المصرية، 2009م.

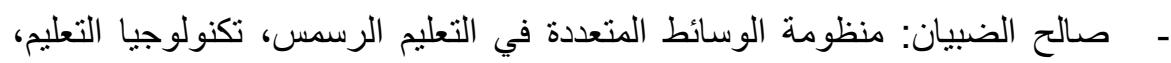
در اسات عربية، تحرير مصطفى عبد السميع، القاهرة، دار الكتاب للنشر ، الفئ 1999م.

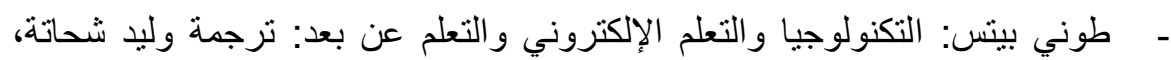

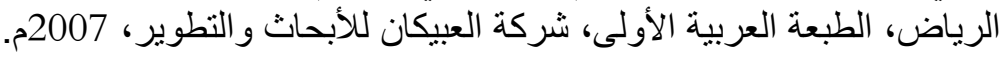

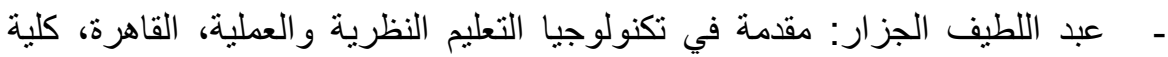

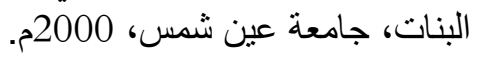
- عبد اله الموسى وأحمد المبارك: التعليم الإلكتروني الأسس والتطبيقات، الرياض، مؤسسة شبكة البيانات، وألة 2005م. عبد الحميد بسيوني: تاريخ ومستقبل الكمبيوتر،ابن سيناءالقاهرة، 2001م.

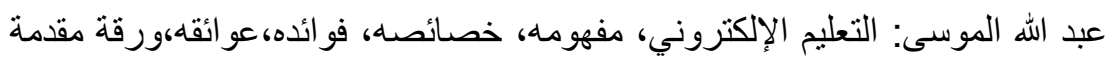
إلى ندوة مدرسة المستقبل ،جامعة الملك سعود، 1423 الإكهـ غريب زاهر إسماعيل: تكنولوجيا المعلومات وتحديث التعليم، القاهرة ،عالم الكتب، 2001م. - - كمال زيتون: تكنولوجيا التعليم في عصر المعلومات، القاهرة، عالم الكتب، 2001م.

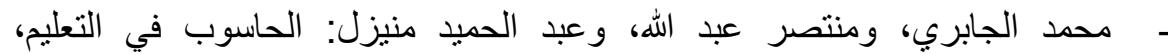

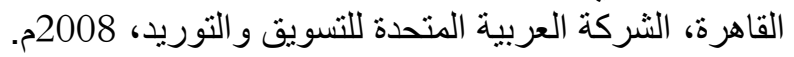
- محمد رضا البغدادي: تكنولوجيا التعليم والتعلم، القاهرة دار الفكر العربي الطبعة التورة

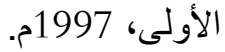
- محمد عطية خميس: مستويات قراءة الصور لاى الأطفال من 4-109 سنوات

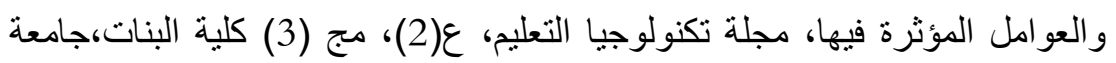
عين شمس، 1993م. - - محمود إسماعيل صيني: المعينات البصرية في تعليم اللغة، جامعة الملك سعود،

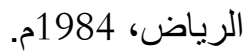


- مصطفي دعمس: تكنولوجيا التعليم وحوسبة التعلم، عمان، دار غيداء، الأردن،

- ميساء أبو شنب: تكنولوجيا تعلم اللغة العربية في الحلقة الأولى من التعليم

الأساسي،رسالة ماجستير مقدمة إلى مجلس كلية الآداب و التربية و الاكاديمية العربية

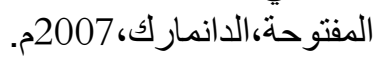

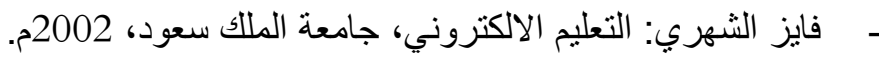

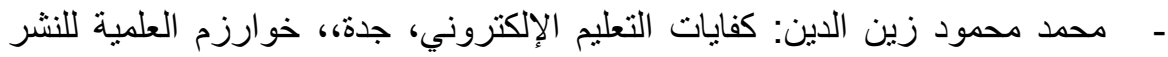
و التوزيع،2007م.

- محمود محمود عفيفي: التطورات الحديثة في تكنولوجيا المعلومات، القاهرة، مطابع

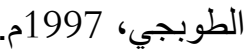

- محد منير مرسي: الإصلاح و التجديد التربوي في العصر الحديث، عالم الكتب،

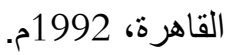

- محمد عبد الحمبد عمار ونجوان حامد القباني: التفكير البصري في ضوء تكنولوجيا التعليم، القاهرة، دار الجامعة الجديدة، 2001م.

- مصطفى عبد السميع محمد: تكنولوجيا التعليم، القاهرة، مركز الكتاب للنشر،

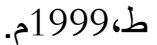

- مصطفى عبد السميع محمد: تكنولوجيا التعليم، مفاهيم وتطبيقات، دار الفكر، القاهرة 2004م.

- هيفاء بنت فهد المبيريك: تطوير طريقة المحاضرة في التعليم الجامعي باستخدام

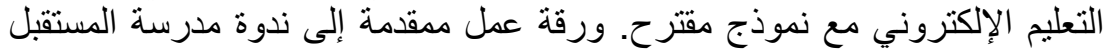

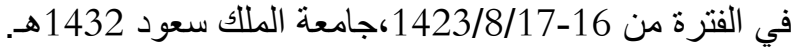

- هيفاء رضا: بيئة مدرسة المستقبل نظرة مستقبلية نحو استر اتيجية ومؤسسية لمفهوم

التعاون. ورقة مقدمة إلى جامعة الملك سعود في ندوة مدارس المستقبل، فئلة 2002م.

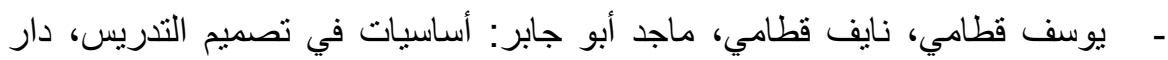
الفكر العربي، عمان، الأردن، نافي، 2001م.

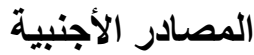

Graham, Neill, (1989): The Mind Tool:Computer\&Their Impact on Society. West publishing company, Minnesota

Greenbelt, C.S., (1975): Teaching with Simulation Games: A Review of Claims and Evidence. In C. S. Greenbelt and R.D Duke (Ed) Gaming Simulation, New York, Widely

Porter, John, (1975): Equality and Education, Integrated Education.

Taylor, (1980) The Computer in The School: Tutor. Tool, Tutee. Teachers College press, Columbia University, New york. 
زكي أبو النصر البغدادي 